Article

\title{
Sustainable Entrepreneurship at the Bottom of the Pyramid: An Identity-Based Perspective
}

\author{
Jackson Musona *®D, Kaisu Puumalainen, Helena Sjögrén and Anna Vuorio \\ School of Business \& Management, Lappeenranta-Lahti University of Technology, LUT, P.O. Box 20, \\ 53851 Lappeenranta, Finland; kaisu.puumalainen@lut.fi (K.P.); helena.sjogren@lut.fi (H.S.); \\ anna.vuorio@lut.fi (A.V.) \\ * Correspondence: jackson.musona@lut.fi; Tel.: +358-503306465
}

\section{check for} updates

Citation: Musona, J.; Puumalainen, K.; Sjögrén, H.; Vuorio, A. Sustainable Entrepreneurship at the Bottom of the Pyramid: An Identity-Based Perspective. Sustainability 2021, 13, 812. https://doi.org/10.3390/ su13020812

Received: 23 November 2020

Accepted: 12 January 2021

Published: 15 January 2021

Publisher's Note: MDPI stays neutral with regard to jurisdictional claims in published maps and institutional affiliations.

Copyright: (c) 2021 by the authors. Licensee MDPI, Basel, Switzerland. This article is an open access article distributed under the terms and conditions of the Creative Commons Attribution (CC BY) license (https:// creativecommons.org/licenses/by/ $4.0 /)$.

\begin{abstract}
Entrepreneurial behavior research has widened its scope to focus on founders who engage in creating enterprises for both their economic self-interest and their concern for others. Yet, there is a lack of an empirically grounded understanding of the sustainable enterprise creation behavior of entrepreneurs at the bottom of the pyramid. This study contributes to sustainable entrepreneurship and entrepreneurial behavior literature streams by applying founder identity theoretical perspectives to explore and understand bottom of the pyramid entrepreneurs' self-perceived identities in the creation of sustainable enterprises. The study applies a multiple case study design with qualitative data collected through field observations and in-depth interviews with enterprise founders and stakeholders. The data were complemented with secondary materials such as websites, founder blogs, online videos, news articles, and other media coverage. The data were analyzed in stages through thematic analysis. Findings show that sustainable entrepreneurs at the bottom of the pyramid possess multiple frames of reference, basic social motivations and adopt either single or multiple role identities, which influence their behavior during the process of creating their enterprises. Moreover, the analysis reveals that Fauchart and Gruber's social identity typologies and the role identities of Cardon et al. can be applied to entrepreneurs at the bottom of the pyramid to understand their identity profiles and illuminate on how these identities result in observed behavioral differences during the process of creating their enterprises.
\end{abstract}

Keywords: bottom of the pyramid; developing country; entrepreneurial behavior; founder identity; role identity; social identity; sustainable entrepreneurship

\section{Introduction}

Recently, there has been a surge in scholarly interest in the role that businesses play in addressing environmental, social, and developmental challenges [1-3]. Consequently, sustainable entrepreneurship emerged as part of a broader paradigm shift from the business-as-usual approach, to creating extra value by increasingly focusing on societal and environmental outcomes [4,5]. Sustainable entrepreneurship is a form of entrepreneurship, which focuses on creating three types of values, namely social, environmental and economic [6]. The emerging sustainable entrepreneurship literature suggests that entrepreneurs' capacity to innovate towards environmental and social challenges sustainably transforms economies [7,8]. Equally, bottom of the pyramid (BOP) entrepreneurs, can act as catalyst for sustainable development through their innovative approaches to entrepreneurship coupled with creative thinking [9]. BOP entrepreneurs are actors who engage in entrepreneurial activities within markets involving approximately four billion consumers with an annual per capita income of less than $\$ 1500$ [10]. The World Bank describes the BOP as consisting of individuals living below or near the poverty datum line of around \$3975, in purchasing power parity [11]. However, despite income, resource and other contextual constraints, BOP entrepreneurs can significantly contribute to global sustainability through their entrepreneurial activities that harmoniously combine economic 
welfare with societal and environmental goals [12]. Scholars are increasingly paying attention to entrepreneurial opportunities deriving from environmental degradation and how these opportunities establish foundations for current sustainable entrepreneurship models, e.g., [13,14]. Although relatively much is known about recognition of opportunities leading to sustainable entrepreneurship [14,15], there remain major knowledge gaps in the sustainable entrepreneurship field [16].

Specifically, the question of whether and how the process of sustainable entrepreneurship might unfold from opportunity recognition to opportunity scaling, and the behavior thereof, still remains a black box [17]. Scholars e.g., Lumpkin et al. [18] and Nicolopoulou [19] have also pointed out that the dynamic processes leading to the founding of new sustainable enterprises have received limited systematic examination and thus largely remain unexplored $[20,21]$. Similarly, another study suggested more elaborate studies that consider decisions made by entrepreneurs in relation to the recognition and development of not only commercial opportunities but entrepreneurship opportunities related to sustainability [22]. In the context of developing countries' entrepreneurial activities, there is only limited understanding about how and why entrepreneurs integrate the often conflicting economic, environmental, and social goals to successfully transition through the enterprise creation process. Drawing on insights from recent studies that have linked identity theory to entrepreneurship $[23,24]$, this study responds to calls to contribute to the identified gaps in the growing sustainable entrepreneurship literature stream $[7,14,22,25,26]$.

An identity-based process view of sustainable enterprise creation is considered by arguing that, as new enterprises are strongly driven and shaped by the characteristics and vision of their founder in the early stages of their establishment, applying founder identities would open more insights into the diversity in entrepreneurial behavior and outcomes. Thus, the study builds on social and role identity theories $[27,28]$ and sustainable, environmental and social entrepreneurship literature streams $[7,29-31]$ to explore the relationship between founder identity and sustainable enterprise creation at the BOP. Social identity refers to the "self' that an individual derives from social group or category membership [32]. Whereas role identity is defined as the "self' that an individual derives from the roles he or she adopts, that are subject to specific expectations. While prior research has empirically explored and elaborated on existing primary social identity prototypes among firm founders e.g., [24], whether these are applicable in the context of BOP entrepreneurship is still to be fully examined. Entrepreneurial identities refer to cognitive representations of interpretations and meanings distinctive of entrepreneurs, providing them with a peculiar identity, motivating behavior, and guiding appropriate role behaviors [33]. An identity is related to the type of opportunity that nascent entrepreneurs pursue and could also explain varying levels of entrepreneurial self-efficacy [34]. Additionally, the heterogeneity of the roles and identities that entrepreneurs apply as they undertake their activities is reflected by the diversity in entrepreneurial behavior [35]. Extant entrepreneurship literature shows that research on the nexus between identity and sustainable entrepreneurship is still nascent. Only a few studies have explored, for example, how a founder's identity awareness helps in overcoming business model and social relationship gaps [36]. Similarly, other scholars have examined the role of identity strategies in shaping organizations [37], and how the strength and/or prioritization of identity coupling determines enterprise goals [38].

This study argues that examining entrepreneurs' social and role identities in distinct phases of the sustainable enterprise creation process [35] and in different contexts [39] has the potential to enrich the sustainable entrepreneurship research by offering additional insights into the influence that these identities have on sustainable entrepreneurial activity [33]. In addition, it has been suggested that BOP entrepreneurship differs from mainstream entrepreneurship in terms of process and underlying values and motivations in the communities from which it emerges $[40,41]$. This suggests that understanding BOP actors' entrepreneurial activities and approaches to sustainability becomes of paramount importance [12]. Thus, the following research questions are examined: (i) How do founders 
of sustainable enterprises at the BOP identify themselves as entrepreneurs? and (ii) How do these identities shape the enterprise creation process? In attempting to answer these questions, the study draws from social and role identity theories $[24,28]$ through seven in-depth qualitative case studies of sustainable entrepreneurs from Kenya. Thus, the study seeks to understand the self-perceived identities of sustainable entrepreneurs and how over time, their self-conceptualizations influenced the process of choosing what to do and expect at distinct phases of creating their enterprises. As such, the main contribution of this study is to combine two important research streams; identity and sustainable entrepreneurship, through a less studied context to enhance the understanding of sustainable entrepreneurship. Through this approach, the study will highlight the heterogeneity in sustainable entrepreneurial behavior and outcomes arising from differences in founder identities, which determine the way sustainable entrepreneurs integrate commercial, environmental, and social goals in sustainable enterprise creation.

\section{Theoretical Background}

\subsection{Identity in Entrepreneurship}

Scholars in the identity research have strongly relied on two theoretical perspectives: social identity theory [32] and identity or role identity theory [28]. These theories emerged from fields of social psychology and sociology, respectively. Founder identity, which is of interest to this study, refers to an individual's understanding of "who am I", "what is my role in society", and "who do I want to be" as an entrepreneur [23,24]. Founder identity encompasses role identity - an individual's interpretation of what it means to be an entrepreneur [42], as well as social identity - the self-concept an individual derives from membership in certain social groups or categories [32]. While the "self" in identity or role identity theory derives from a person's roles as subjected to specific expectations [43], social identity theory views the "self" as based on a social group that an individual identifies with and is expected to think and behave like members of such [32]. Thus, integrating the two theoretical perspectives results in a comprehensive view of identity as deriving from the self and society, which mutually shape and influence each other ([44], p. 3). The growing academic interest in identity in entrepreneurship reflects the recognition of the centrality and influence of identity on entrepreneurial behavior [45-47]. Scholars that draw from identity and social identity theories have argued that individuals see themselves according to the roles they occupy, including role identities related to being an entrepreneur or founder $[48,49]$ and social identities aligned to the social groups that they belong to and associate with [24].

Prior studies linking social identity theory and entrepreneurship suggest that an entrepreneur's social identity influences the type of an opportunity they exploit $[24,36,50,51]$. Moreover, the diversity in entrepreneurial behavior reflects the heterogeneity of the roles and identities entrepreneurs apply as they go through their entrepreneurial endeavors [35]. This study builds on the identity-based view of entrepreneurs as individuals involved in both enterprise creation and pursuance of entrepreneurial activities that afford substantial self-meaning [52]. However, it should be noted that how the categorization and self-definitions of entrepreneurs develop $[44,48]$ is beyond the scope of this study. Based on the presumption that entrepreneurs establish enterprises based on self-identities ([47], p. 3), prior studies have applied the identity perspective to explain entrepreneurs' different motivations to engage in entrepreneurial activities, their strategic actions, as well as their decision making $[24,53,54]$. Recent studies have also shown that entrepreneurs' identities systematically influence important entrepreneurial decisions and outcomes $[24,38,54]$. The combination of identity and entrepreneurship research streams has resulted in the labelling of entrepreneurs as individuals who find meaning based on their engagement with entrepreneurial activities [53]. This results in the formation of one or more role identities related to a specific subset of entrepreneurial activity or multiple entrepreneurial activities [53,55]. The prior research on role identities in entrepreneurship has introduced three specific role identities, namely inventor, founder, and developer [53]. Inventing refers to 
searching for new market opportunities, developing new products or services, and finding new solutions for important needs and problems. Founding relates to assembling the necessary financial, human, and social resources needed to create a new enterprise, and developing is associated with the growth and expansion of the enterprise after founding [53]. While Fauchart and Gruber [24] employed social identity theory to conclude on the existence of Darwinians, communitarians, and missionaries as pure types of founder social identities based on differences in the dimensions of basic social motivation, frame of reference or relevant other, and basis of self-evaluation. In explicating these dimensions of the three different social identities identified amongst entrepreneurs, Fauchart and Gruber [24] outlined that the Darwinian entrepreneur is motivated by economic self-interest, considers competitors as relevant others and regards professionalism as basis of self-evaluation. On the other hand, the communitarian's basic social motivation is to support and be supported by a given community, they view a social group benefiting from the product or service as their frame of reference and authenticity as basis of self-evaluation. Lastly, missionary entrepreneurs consider "advancing a cause" as their basic social motivation, with responsible behavior as their basis of self-evaluation and the society as the primary frame of reference [24]. Therefore, Darwinians launch enterprises with their economic self-interest in mind, while communitarians, and missionaries engage in entrepreneurship because of concern for known and unknown others respectively.

Going forward, this study argues that the self-categorization principle of role and social identity theories is important in achieving the study's objective of illuminating how self-perceived identities of entrepreneurs' influence recognition, development, and scaling of opportunities related to sustainability. This is because, in role identity theory, individuals self-categorize based on roles that can be internalized and enacted to determine behavior and the path that an enterprise will take [47]. Whereas, in social identity theory, individuals self-categorize into certain social groups or categories from which they derive action, since belonging to groups or categories shapes behavior [56]. Integrating key tenets of these two theories, which is of particular importance to this study, would mean that individuals are simultaneously engaged in self-categorization into certain role categories as well as certain social or group categories, which becomes central in the process of defining "who they are" and "what they want to be". Internalization and enactment of expectations from different self-categorized relational categories and of membership in a particular social group can significantly determine creation, path and outcomes of an enterprise [47]. By belonging to a social category, and thus expected to exhibit certain behaviors consistent with being a member of that group, entrepreneurs are constantly reflecting on what it means to be a member of a group that they identify with, resulting in prototypical behaviors [24] and decisions [57] that shape the entrepreneurial process.

The presumption is that the expected behavioral standards of self-categorized role identities that entrepreneurs assume in the context of their enterprises, and the need to belong to and act in accordance with the dictates of certain self-categorized social groups, would have a significant influence on the types of opportunities that entrepreneurs recognize and the actions that they take to develop and scale-up these opportunities. In line with the foregoing, Conger et al. [16] argued that entrepreneurs' act of choosing to identify with certain social groups can result in their enactment of definitive strategies and pursuance of some opportunities while avoiding others. Research on founder identity has focused on identifying common founder characteristics such as dedication to discovering and exploiting new opportunities, risk taking proclivity, and passion for being leader of a new enterprise [49]. Similar studies have suggested that founders can construe their identities in ways that prioritize different entrepreneurial characteristics, motivations, and behaviors [24,53]. However, even though scholars' interest in identity in entrepreneurship has increased, only a few studies to date have provided insights on the notion of founder identity and its behavioral effect on an emerging organization [24]. Particularly, even though models that explain entrepreneurship in BOP contexts may exist [30,58], they seem to ignore an important source of dynamism and heterogeneity that is due to differences in individuals' conceptions of the founder role 
and variation in the subjective importance that individuals place on becoming a founder [21]. Specifically becoming an entrepreneur founding an enterprise focusing on issues related to sustainability. Therefore, it seems that an identity perspective on sustainable enterprise creation, accounting for key role and social aspects of the concept of "self", can yield important insights about sustainable entrepreneurship at the BOP, contributing to the broader field of sustainable entrepreneurship.

\subsection{Sustainable Entrepreneurship}

Over the past decade, scholars have paid increasing attention to the use of entrepreneurship as a vehicle for promoting creation of ecological and social value. This has led to an upsurge in studies focusing on social entrepreneurship [29,59-61], environmental entrepreneurship [38,62,63], and sustainable entrepreneurship [7,20,64]. Sustainable entrepreneurship relates to entrepreneurial activities that generate economic value while at the same time focusing on ecological and social outcomes [7,17,64]. Prior studies about entrepreneurs and their activities have enhanced an understanding of sustainable entrepreneurship by exploring questions related to, for example; (i) motivations and contribution to sustainability, (ii) managing the tensions and blurring boundaries between social, environmental, and economic goals, and (iii) mobilization of resources for sustainable entrepreneurial activities $[7,17,33,38,62]$. This body of literature argues that sustainable entrepreneurs are motivated by identities based on both commercial and or ecological logics to sequentially integrate the triple bottom line of social, ecological, and economic goals [20,38,65]. Thus, compared to traditional entrepreneurs, sustainable entrepreneurs have different motivations for starting an enterprise.

Sustainable entrepreneurs pursuing opportunities with environmental, economic, and social benefits pay attention to different facets of their environment as opposed to those who focus mainly on opportunities with pure economic gains $[13,15]$. They recognize changes to the physical biosphere and develop environmental preservation opportunities [66], leading to their engaging in for-profit entrepreneurial activities that generate social and environmental value [14]. When exploiting an opportunity, sustainable entrepreneurs, through their ecological logic, prioritize addressing environmental challenges while ascribing economic efficiency and profits through a commercial logic [38,67]. They must find balance between the creation of social and environmental value and the creation of private value, making their goals broader and more complex than ordinary entrepreneurs [68,69]. Sustainable entrepreneurs are considered as facing these specific challenges related to the balancing of often conflicting commercial, ecological, and social logics when establishing their businesses [70]. A study by Hoogendoorn et al., [71], shows that sustainable entrepreneurs had more negative expectations when setting up a business in terms of financial, administrative, and information support.

Thus, the possibility of personal failure seems to be central in the context of sustainable entrepreneurship. However, non-existence of significant differences between sustainable and traditional entrepreneurs in terms of attitudes towards business risks was also reported [71]. Instead, the scholars found sustainable entrepreneurs to possess greater fear of personal failure than traditional entrepreneurs. It seems that finding a balance between social and economic values is even more challenging in emerging markets [72]. Indeed, sustainable entrepreneurs typically operate in challenging operating environments because imperfect markets and the possibility of failure also offer opportunities [13,69]. Thus, this study draws on social, environmental, and sustainable entrepreneurship literature. As sustainable entrepreneurship is closely related to the fields of social and environmental entrepreneurship [7,73], it can be also assumed that when drawing on the argumentation of these fields, similar arguments would apply to sustainable entrepreneurs. BOP markets offer potential growth to entrepreneurs who can innovate and create enterprises that offer the required goods and services $[58,74]$. However, the markets are underdeveloped, and have poor infrastructure and customers, with several institutional voids, information asymmetries and high resource constraints [75]. Due to institutional voids that lead to the absence 
of more formal structures such as laws and regulatory agencies, informal structures and practices like family and kinship are important in BOP entrepreneurship [76]. It is widely known that small business dominates the economy in most developing countries. Therefore, the small business owner plays an important role in the economic development of developing countries. However, the owners of these small businesses-the entrepreneurs, are not yet sufficiently known $[77,78]$. In terms of sustainability, BOP entrepreneurs have been described as a critical source of growth of sustainable innovations that may contribute to a shift towards more sustainable production and consumption systems [79]. Furthermore, BOP entrepreneurs focusing on solving environmental and social problems have been labelled as the future of global sustainability through their innovation activities that harmoniously combine economic, social, and ecological goals [12].

BOP sustainable entrepreneurs can potentially deliver sustainable sociotechnical solutions to many problems including waste, energy, health care, and food, leading to a transition towards more sustainable ways of production and consumption [80]. Thus, the question of whether sustainability-driven innovation and entrepreneurship occurs at the BOP has been previously explored e.g., $[12,81,82]$. However, the BOP entrepreneurship literature lacks a process perspective on how entrepreneurs create enterprises focusing on issues related to sustainability. The noticeable increase in relevance and contribution to sustainability demonstrated by non-traditional entrepreneurs [12] has led to intensified calls to better understand the emergence, processes, dynamics, and framing of locallyfocused accounts of sustainable entrepreneurship in the face of resource scarcity [83]. While operating in highly uncertain resource-constrained and poverty-stricken environments [84], sustainability-driven entrepreneurs at the BOP strive to create economic value by combining social and environmental goals [12]. Given that multiple goals make sustainable entrepreneurship more complex [20], together with the resource-constrained nature and low competences of entrepreneurs in developing countries [85], it would be prudent to assume they would be less motivated to recognize and pursue sustainability-related entrepreneurship opportunities. Thus, based on this presumption, individuals that recognize and pursue opportunities related to sustainability at the BOP must be distinctive in their perception of who they are. Therefore, understanding these individuals from an identity perspective is important in unravelling sustainable entrepreneurship at BOP and thus contributing to the broader sustainable entrepreneurship literature. Scholars in the sustainable entrepreneurship field, for example, York et al. [38] encourage identity-based approaches to advance theorizing that encompasses economic, social, and ecological aspects of entrepreneurial action. By applying an identity lens, fundamental aspects of an individual's identity, which are relevant to sustainable entrepreneurship in the BOP context, are captured.

\section{Materials and Methods}

Given the explorative nature of the research questions, a qualitative interpretive approach based on a multiple case study research strategy was employed [86,87]. The multiple case study research strategy enables a "real life context" investigation of a contemporary phenomenon ([88], p. 13), while allowing replication, with each additional case used to confirm insights emerging from data [89]. A case study is considered as the appropriate research methodology when examining "how" and "why" questions [87]. Seven founders and leading co-founders of enterprises from Kenya who created businesses involved in the development of value-added products using different types of waste were purposively selected. Sampling proceeded according to case relevance as opposed to representativeness [90]. When selecting the cases, the following criteria were used: (i) individuals who created enterprises that offer demonstrable environmental and societal value with strategic actions while simultaneously creating economic value, (ii) respondent who is a founder or leading co-founder and still in charge of the enterprise, (iii) respondent whose enterprise has reached commercialization, either formerly registered or not yet registered but with a sustainable product or service already on the market, (iv) respondent who founded or 
co-founded an enterprise during the last 10 years up to the point of data collection-to be able to capture the process in detail, with founders presumed to still have fresh memories of how they started. To identify entrepreneurs that suit these criteria, a two-step process was applied. First, the Entrepreneurship for Sustainable Development website SEED (for details see; https: / / seed.uno/) was consulted. This website contains a database of entrepreneurs in developing and emerging markets aspiring to or already engaged in social and environmental entrepreneurship. Second, the entrepreneurs identified through the SEED database were asked to provide referrals to entrepreneurs to participate in the broader project on sustainable innovations in developing countries. Additionally, some cases were also identified through media reports.

\subsection{Data Collection}

Initially, after identification of suitable cases through referrals and media reports, telephone interviews were conducted during the winter of 2017, followed by interviews and field observations during the years 2018, 2019, and 2020. Initial telephone interviews were key in assessing the respondents' suitability for the study, getting confirmations about their willingness to participate in the study, as well as familiarity with the respondents to facilitate 'opening up' to questions during interviewing. The interviews were conducted on site, with the help of a research assistant who is a native. Having a native research assistant helped in having easy access to the respondents while also creating an environment where the respondents could freely express themselves, sometimes in their native language. In few instances where native language was used, the research assistant helped in translating the content into English. Each interview lasted around 50 to $120 \mathrm{~min}$. During the interviews, life stories of the respondents formed a key component of the data on self-perceived identities in the recognition, development, and scaling of opportunities related to sustainability. In this study, life narratives are considered to provide information on who the individuals are (and who they are not), who they want to be, and how they work towards who they want to be. The number of rounds of interviews and field observations per respondent varied depending on respondents' availability and reaching saturation. Table 1 presents an overview of the respondents' profiles and data collection details.

For anonymity, pseudonyms are used instead of respondents' real names and those of their enterprises. Stakeholder interviews, field notes, news articles, enterprise websites, and other materials such as videos also provided information that was useful in aiding the analysis through triangulation. Secondary data provided background information on aspects such as launching of the enterprise, the sources and nature of support received, the founders' engagements to communicate the enterprise's environmental and social objectives, and how the founders developed and enacted their business models. Altogether, there was 191 pages of transcribed interview material and 3 pages of field notes. In terms of secondary data, 11 pages of news articles and 121 min of videos and television features were accumulated to support the analysis through triangulation. Data collection took place for a period of over two years, with the objective of getting as much information as possible from the respondents until saturation was reached. Moreover, simultaneous data collection and data exploration were utilized to identify key themes and categories in the data, aiding in narrowing down the interviewing process to pertinent issues of interest. All interviews were administered by the first author, recorded and later transcribed verbatim. Follow-up interviews for verifying facts and validating emerging themes were conducted via Skype and phone calls. 
Table 1. Respondents and data collection details.

\begin{tabular}{|c|c|c|c|c|c|c|}
\hline Founder/Co-Founder & Name of Enterprise & Founding & Business Type & Number of Interviews & Interview Year & Other Data Sources \\
\hline Don & BI Energy & 2011 & $\begin{array}{l}\text { Innovative renewable } \\
\text { energy solutions }\end{array}$ & 1 & 2018 & $\begin{array}{l}\text { Website, brochures, stakeholder } \\
\text { interviews, online videos, news } \\
\text { articles, participant observation. }\end{array}$ \\
\hline Oscar & Green Con & 2010 & $\begin{array}{c}\text { Alternative } \\
\text { construction materials } \\
\text { from recycled plastic } \\
\text { waste }\end{array}$ & 2 & 2018,2019 & $\begin{array}{l}\text { Website, news articles, online videos, } \\
\text { stakeholder interviews, i.e., local } \\
\text { incubator, participant observation }\end{array}$ \\
\hline Melvin & EBT Materials & 2017 & $\begin{array}{l}\text { Alternative building } \\
\text { materials from } \\
\text { recycled plastic \& glass } \\
\text { waste }\end{array}$ & 2 & 2018 & $\begin{array}{c}\text { Website, founder blogs, news articles, } \\
\text { online videos, stakeholder interviews } \\
\text { i.e., local incubator, participant } \\
\text { observations }\end{array}$ \\
\hline Gregory & MB Energy & 2013 & $\begin{array}{l}\text { Eco-friendly briquettes } \\
\text { from biomass waste }\end{array}$ & 1 & 2018 & $\begin{array}{c}\text { Online videos, stakeholder interviews } \\
\text { i.e., local incubator, participant } \\
\text { observations }\end{array}$ \\
\hline Sam & SO Agro & 2015 & $\begin{array}{l}\text { Organic fertilizers } \\
\text { from biomass waste }\end{array}$ & 2 & 2018,2019 & $\begin{array}{c}\text { Website, founder blogs, news articles, } \\
\text { online videos, participant } \\
\text { observations }\end{array}$ \\
\hline Jan & QI Engineering & 2016 & $\begin{array}{l}\text { 3D printers from } \\
\text { e-waste and printing } \\
\text { services using plastic } \\
\text { waste, automation }\end{array}$ & 1 & 2018 & $\begin{array}{l}\text { Website, stakeholder interviews i.e., } \\
\text { local incubator }\end{array}$ \\
\hline Patrick & PB Enterprises & 2013 & $\begin{array}{l}\text { Eco-friendly briquettes } \\
\text { from biomass waste }\end{array}$ & 2 & 2018,2020 & $\begin{array}{c}\text { Online videos, stakeholder interviews } \\
\text { i.e., local incubator. }\end{array}$ \\
\hline
\end{tabular}




\subsection{Data Analysis}

The data was initially analyzed in detail through a case-by-case approach and later across cases. The analysis was carried out in three steps. First, the interviews were carefully read to get detailed accounts by each respondent as a way of making sense of the text [91]. After reading, open coding was applied to the data [92]. This was done to understand identity dimensions and other variables intervening at each of the distinct phases of the enterprise creation process. Initially, there was a first round of open coding involving the first author and another coder who acted as an outsider and was not involved in data collection. After the first round of open coding, a second round of coding ensued, involving the two coders discussing individual codes and agreeing on the final codes. Thus, initial codes emerged from informant-centered codes that were based on common themes and statements identified by both coders. During the process of developing initial codes, there was robust discussion and agreeing on the codes on. This played an important role in determining the final themes. Second, after discussing and agreeing on the initial codes, relationships both between and within the initially agreed codes were jointly searched for, combining related first order codes into second order interpretive themes [93]. The second order interpretive themes were developed as reflective of the data's core elements in order not to lose meaning. As this was happening, the emerging empirical insights with theory were confronted [94], moving back and forth between different data sources and theory until the data could not give out any new insights. This resulted in the identification of what was thought to be new or additional themes and thus led to the development of data clusters relevant in answering the research questions. At this stage, similarities and differences across cases were compared for each emerging theme.

Lastly, the second order interpretive themes were combined into final thematic dimensions, reflective of self-perceived social and role identities. In analyzing the respondents' social identities, Fauchart and Gruber's typology was applied: Darwinians, communitarians, and missionaries. Moreover, to determine the salience of a role identity by each respondent, three aspects of role and role identities were considered in accordance with Powel and Baker's coding, albeit with slight adjustments. The three adjustments in role and role identity coding were: (i) incumbent says (I have this role), (ii) incumbent says others say (others say I have this role), and (iii) incumbent says other does (incumbent says others behave as if I have the role). In rare circumstances, role conceptualizations were derived from incumbent behavior during the field observations. Therefore, the data was coded considering these types of role and role identity evidence. Each respondent was designated with a role identity salience only if at least two types of the evidence listed above could be identified. The codes for roles and role identities were ultimately aggregated using the distinction of Cardon et al.'s inventor, founder, and developer identities. See Tables A1 and A2 in appendices for details about the final data structure of the social and role identities, respectively. Using the second order interpretive themes and aggregate dimensions of the data analysis process together with existing literature, an identity-based process model that provides a theoretical explanation of recognition, development, and scaling of opportunities by sustainable entrepreneurs at the BOP was developed.

\section{Results}

The study was guided by two main objectives. First, to explore BOP entrepreneurs' self-perceived identities as founders of sustainability focused enterprises, and second, to understand the link between entrepreneurs' identities and the enterprise creation process. In achieving these objectives, Fauchart and Gruber's [24] founder identity typologies and Cardon et al.'s [53] distinctive role identities were key, because the data was coded and analyzed in light of these existing identities and identity dimensions. Table 2 shows a summary of the social identity saturations and salient role identities identified for each respondent. Next, role-related behaviors of each respondent at distinct phases of the enterprise creation process were examined to unpack the identity-based sustainable enterprise creation process. 
Table 2. Social identity saturation and salient role identities by respondent.

\begin{tabular}{cccccccc}
\hline & Don & Oscar & Gregory & Jan & Melvin & Patrick & Sam \\
\hline $\begin{array}{c}\text { Frame of } \\
\text { Reference/relevant others }\end{array}$ & ${ }^{*} \mathrm{C} / \mathrm{M} / \mathrm{D}$ & $\mathrm{C} / \mathrm{M} / \mathrm{D}$ & $\mathrm{D} / \mathrm{C}$ & $\mathrm{D}$ & $\mathrm{C} / \mathrm{M} / \mathrm{D}$ & $\mathrm{C} / \mathrm{M} / \mathrm{D}$ & $\mathrm{C} / \mathrm{D}$ \\
$\begin{array}{c}\text { Basic Social Motivation } \\
\text { Basis of Self-evaluation }\end{array}$ & $\mathrm{C} / \mathrm{M}$ & $\mathrm{C} / \mathrm{M}$ & $\mathrm{D}$ & $\mathrm{D}$ & $\mathrm{C} / \mathrm{M} / \mathrm{D}$ & $\mathrm{C} / \mathrm{M}$ & $\mathrm{C} / \mathrm{M}$ \\
Salient Role identities & $\begin{array}{c}\mathrm{C} / \mathrm{M} \\
\end{array}$ & $\mathrm{D}$ & $\mathrm{D}$ & $\mathrm{C} / \mathrm{M}$ & $\mathrm{C}$ & $\mathrm{C} / \mathrm{M}$ & Inventor \\
& Developer & $\begin{array}{c}\text { Inventor/ } \\
\text { Developer/ } \\
\text { Founder }\end{array}$ & Developer & $\begin{array}{c}\text { Inventor/ } \\
\text { Developer }\end{array}$ & Developer & Developer & IDeveloper \\
\hline
\end{tabular}

${ }^{*}$ C-communitarian, D-Darwinian and M-missionary.

The study establishes variations in the self-worth that respondents seek to obtain in becoming sustainable entrepreneurs. The results show that the respondents exhibited various degrees of saturation of dimensions of the three social identity types of Darwinians, communitarians, and missionaries (see Table 2 above). A considerable number of the respondents exhibited hybrid identity features-a combination of characteristics of the pure types in a single identity dimension. As a result, two respondents are classified as pure Darwinian. These two founders' basic social motivations were mainly anchored on personal economic self-interest and therefore put much emphasis on devising competitive products and services that differentiated them from other market players. For example, Gregory started an enterprise for self-employment and personal income generation after failing to secure formal employment: "after graduating, white-collar jobs did not come so fast and I needed a source of income. So, I started researching on ways to earn money on the Internet. Through internet research, I discovered that people were getting money from making and selling briquettes. I did this research and in 2013 I started making briquettes." Gregory considered coming up with a product that was distinct from conventional products as core to the entrepreneurial process and to the success of the enterprise, and thus deployed competencies for product quality and affordability: "I was so confident with the quality of my briquettes, so even if charcoal and firewood are direct competitors to my briquettes, mine are a little bit affordable and of high quality." Respondents with Darwinian identity type view professionalism as their basis of self-evaluation. For example, Jan, who is also a Darwinian, derived self-worth from being able to professionally design and develop products and services that attract customers to generate revenue that leads to enterprise growth.

However, five out of the seven respondents had identity profiles consistent with characteristics of either all the three pure types or any two pure types in a single identity dimension. For example, looking at the basic social motivation dimension, Oscar was inspired to address social challenges and therefore desired to support and be supported by the local community as he engaged in activities positively impacting the community and the immediate natural environment $(\mathrm{C})$ while establishing multiple enterprises, each focused on "advancing a cause" (M), for example, the general belief in the efficacy of local innovative ideas in solving Kenya's affordable housing challenges. Oscar expressed; "I'm naturally inspired to address societal challenges [ . . . ] and societal challenges are common, for example, diseases, housing, food insecurity, and unemployment." To achieve this objective and the associated self-worth, Oscar worked closely with local communities to establish perpetually reinforcing and mutually beneficial relationships: "I needed to do that [establish relationships] to guarantee my supplies to make sure the business keeps running, because without them [community], I'll not be able to run and that's a symbiotic arrangement. They can't do without me; neither can I do without them, that's why it's been built to what it is today." Equally, Don, Melvin, Patrick, and Sam had basic social motivations that encompassed both the desire to support and be supported by a given community while undertaking activities initially aimed at benefiting the same community, and at the same time advancing a cause. Sam explained how he felt obliged to provide a solution to local farmers' drastically lower yields resulting from degraded soils: "our 
product is working to restore degraded soils, meaning farmers would harvest more. You know what that means? This farmer now has more income to send their children to school." Sam's motive to advance a cause, involving restoring soil fertility, was attached to his overall political belief that improved crop yields by local farmers would result in more income, which has several spillover effects that are crucial in economic and social development of local communities and beyond: "we offer training to farmers in terms of improving their livelihoods and improving their farming methods because we believe in one very simple thing, if the farmer succeeds, we are guaranteed we will have success." Respondents with both communitarian and missionary basic social motivation characteristics consider their enterprises as social entities that support and require support from a specific community because of established mutually beneficial relationships. They also consider their enterprises as political entities that translate their personal values and beliefs into a cause that initially benefits a community and later targets the society at large as the business model succeeds and the enterprise grows.

Moreover, the analysis shows that these five respondents had multiple frames of reference. Their frames of reference mostly connote features of all three identity types. This further confirms their hybrid nature in which they follow multiple logics during enterprise creation. For example, Sam who follows both the community and missionary logics. These five respondents pursued both personal and the all-inclusive self-categorizations as they focused their actions and behavior on their personal selves, personal others, and impersonal others. This means that while they worked on providing products and or services that support a known social group (community) and an unknown social group (society), they equally endeavored to be distinct from other people in the same social space. In line with the foregoing, Don, who exhibits the hybrid self-categorization stated: "So, like I said, that's one area that brings the kind of business we are in, we need to help them [the society]. So, we will, certainly!" In this statement, Don explains that the desire to help unknown significant others, led them to expand and venture into mobile pit latrines that his enterprise develops and supplies both as a source of biowaste and as human risk management systems. Don further explained how being different from others worked as a source of competitive advantage: "The business has been good because we are rewriting the books on biogas to a large degree. We are coming up with something different from the conventional biogas and we're demonstrating the conventional one is actually bad." In some other cases of hybridity, respondents described their engagement with activities that uplifted the community, while in a different way, demonstrating the feasibility of alternative social practices: "We brought electricity to the community, I think around eight houses have been able to get electricity from here. Besides that, we are providing an alternative green product, which we also send to the community. The cost savings they are having if they are to buy this alternative material means they are getting that value from us."-[Melvin]. Similarly, Patrick explained: "I had the desire of making something unique from other fabricators. I said, 'How can I help other people?' In fact, my initial thinking was to make the machine and sell to people and I made the machine for several people".

Amongst the five respondents who exhibited hybridity in their basic social motivation and frame of reference, differences in the dimension of basis of self-evaluation as a founder were observed. Some respondents, for example, Oscar, Melvin, and Sam, exhibited hybridity in this dimension. Sam portrayed himself as someone with vast and profound knowledge of the needs and challenges faced by a community of farmers. The knowledge was based on his own personal life experiences of growing up as part of family of peasants. Accordingly, he considered bringing products that meet the needs of a community of farmers and engaging in activities that attended to their challenges as core to the entrepreneurial process: "I do still remember the words of my grandmother, we were in the farm and she said, 'Son, let me tell you, go to school and study really hard because this farm will not be producing by the time you get a family. You need to go study hard and get employed out there, do not come to the farm.' But I asked myself, 'Am I the only person who is depending on agriculture? Or will my children depend on agriculture?' So, yeah, I take my 
children out, are there others who are depending on agriculture? Reality is, yes! Majority of the people are still dependent on agriculture, so, if no one solves their problem, who will? If we all go and run away from the village, who will go back to solve these problems? So, that is how I got an idea of bio char. I knew, definitely, this solves my problem and it solves the problem for millions of other farmers." While bringing products and engaging in activities that are truly useful to a community is considered core to Sam's self-definition, contributing to a better world through his entrepreneurial activities is also considered critical: "this product, when it is buried in the soil, prevents release of carbon (IV) oxide, and according to research done, it is an equivalent of 1.7 tons per acre of land our product is used [on]. That is what we sequester from the environment. So, the more farmers use our product, then the more $\mathrm{CO}_{2}$ we are sequestering." Melvin, who also exhibited hybridity in his basis of self-evaluation, expressed his desire to contribute to a better world and the need to act different as a responsible person who can take action to solve a grand challenge: "Actually, they are warning right now if nothing is done to improve plastic recycling globally, we will have more plastic waste than fish in our oceans by the year 2050 . So, this is scary, and I can't believe why there are not so very many people who are trying to solve it, but it's not as much as is needed to solve the problem. That's the reason why I decided, "let's try and focus on this." Melvin equally associates being a founder and core to the entrepreneurial process, the ability to successfully bring products that are useful to a community: "We are providing an alternative in the form of a green product, which we also send to the community".

Don and Patrick exhibited pure features of a communitarian in their basis of selfevaluation as founders. They strove to bring products or services and engage in activities truly useful to society. For example, Patrick passionately explained how his product turned out to be key alternative source of energy, especially given the government ban on cutting down of trees, "I noticed the environment was an issue and I also provide a solution to people. 'If we tell them not to cut trees, what are they going to use?' So, this comes as the right alternative to firewood. Yes!" The data analysis therefore showed a high level of hybridity amongst five of the cases in terms of their basic social motivation, frame of reference, and partly their basis of self-evaluation as founders. On the other hand, two cases showed features of pure Communitarian in their basis of self-evaluation. In terms of role identities, the analysis revealed the salience of certain role identities. Some of the respondents had multiple salient role identities while others transitioned mainly from the founder role identity to end up with a single salient developer role identity. In one case, founder and other role identities were salient. Refer to Table 2 for details about salient role identities for each respondent.

\subsection{Founder Identities and Sustainable Enterprise Creation}

Table 3 below, shows a summary of the results on the link between founder identity and sustainable enterprise creation. In the next sub-sections, findings are presented and discussed. 
Table 3. Summary of results.

\begin{tabular}{|c|c|c|c|c|c|}
\hline & Don \& Sam & Oscar & Melvin \& Patrick & Jan & Gregory \\
\hline & Communitarian/Missionary & Communitarian/Missionary & Communitarian/Missionary & Darwinian & Darwinian \\
\hline Social identity & $\begin{array}{l}\text {-Seeking to support and be } \\
\text { supported by a community } \\
\text { while advancing a cause. } \\
\text {-Follows a community logic } \\
\text { and later a missionary logic } \\
\text { and derive self-worth from } \\
\text { offering a product or service } \\
\text { through new and innovative } \\
\text { business management } \\
\text { approaches aimed at } \\
\text { transforming a community } \\
\text { and act to pursue a political } \\
\text { vision for establishing a } \\
\text { better world. } \\
\text {-Significant known } \\
\text { others-community, significant } \\
\text { unknown others-society and } \\
\text { competitors as frames of } \\
\text { reference }\end{array}$ & & & $\begin{array}{l}\text {-Pursue private and economic } \\
\text { self-interest } \\
\text {-Follow traditional business } \\
\text { logic and derive self-worth by } \\
\text { acting and behaving in ways } \\
\text { congruent with traditional } \\
\text { business management. } \\
\text {-Competition as the primary } \\
\text { frame of reference }\end{array}$ & \\
\hline Role identity & Inventor/Developer & Inventor/Founder/Developer & Developer & Inventor/Developer & Developer \\
\hline Entrepreneurial behavior & $\begin{array}{l}\text {-Attend to natural and } \\
\text { communal environments-to } \\
\text { explore a new idea. } \\
\text {-Develop new idea focused } \\
\text { on advancing community } \\
\text { and society objectives. } \\
\text {-Adapting new technologies } \\
\text { in new context. }\end{array}$ & $\begin{array}{l}\text {-Attend to natural and } \\
\text { communal environments-to } \\
\text { explore multiple new ideas. } \\
\text {-Develop a new idea focused } \\
\text { on advancing community } \\
\text { and society objectives. }\end{array}$ & $\begin{array}{l}\text {-Attend to natural and } \\
\text { communal environments-to } \\
\text { explore an idea. }\end{array}$ & $\begin{array}{l}\text {-Attuned to market and } \\
\text { information gaps. } \\
\text {-Develops new idea focused } \\
\text { on advancing personal } \\
\text { self-interest. }\end{array}$ & $\begin{array}{l}\text {-Attuned to market and } \\
\text { information gaps. } \\
\text {-Developing traditional } \\
\text { business ideas. }\end{array}$ \\
\hline
\end{tabular}


Table 3. Cont.

\begin{tabular}{|c|c|c|c|c|c|}
\hline Role identity & Inventor/Developer & Inventor/Founder/Developer & Developer & Inventor/Developer & Developer \\
\hline Entrepreneurial behavior & $\begin{array}{l}\text {-Attend to natural and } \\
\text { communal environments-to } \\
\text { explore a new idea. } \\
\text {-Develop new idea focused } \\
\text { on advancing community } \\
\text { and society objectives. } \\
\text {-Adapting new technologies } \\
\text { in new context. } \\
\text {-Enacting new and innovative } \\
\text { business models with a focus } \\
\text { on wider community and } \\
\text { society level impacts. } \\
\text {-Scientific novelty and } \\
\text { science-based decision } \\
\text { making in new } \\
\text { product/service } \\
\text { development. } \\
\text {-Calculated risk taking } \\
\text {-Establishing an enterprise } \\
\text {-for more community and } \\
\text { societal impacts. } \\
\text {-Commercializing and } \\
\text { exploiting an opportunity for } \\
\text { community and societal } \\
\text { value. }\end{array}$ & $\begin{array}{l}\text {-Attend to natural and } \\
\text { communal environments-to } \\
\text { explore multiple new ideas. } \\
\text {-Develop a new idea focused } \\
\text { on advancing community } \\
\text { and society objectives. } \\
\text {-Enacting new and innovative } \\
\text { business models with a focus } \\
\text { on wider community and } \\
\text { society level impacts. } \\
\text {-Scientific novelty and } \\
\text { science-based decision } \\
\text { making in new } \\
\text { products/services } \\
\text { development. } \\
\text {-Establishing multiple } \\
\text { enterprises for more } \\
\text { community and societal } \\
\text { impacts. } \\
\text {-Commercializing and } \\
\text { exploiting multiple } \\
\text { opportunities for community } \\
\text { and societal value. }\end{array}$ & $\begin{array}{l}\text {-Attend to natural and } \\
\text { communal environments-to } \\
\text { explore an idea. } \\
\text {-Establishing an enterprise } \\
\text { with more environmental and } \\
\text { societal impacts. } \\
\text {-Commercializing and } \\
\text { exploiting an opportunity for } \\
\text { community and societal } \\
\text { value. } \\
\text {-Enacting traditional 'ready to } \\
\text { wear' business models. }\end{array}$ & $\begin{array}{l}\text {-Attuned to market and } \\
\text { information gaps. } \\
\text {-Develops new idea focused } \\
\text { on advancing personal } \\
\text { self-interest. } \\
\text {-Commercializing and } \\
\text { exploiting an opportunity for } \\
\text { private, economic } \\
\text { self-interest. } \\
\text {-Scientific novelty in new } \\
\text { product/service } \\
\text { development. } \\
\text {-* R \& D and market } \\
\text { partnerships } \\
\text {-Establishing an enterprise } \\
\text {-Enacting traditional 'ready to } \\
\text { wear' business models. }\end{array}$ & $\begin{array}{l}\text {-Attuned to market and } \\
\text { information gaps. } \\
\text {-Developing traditional } \\
\text { business ideas. } \\
\text {-Commercializing and } \\
\text { exploiting an opportunity for } \\
\text { private, economic self-interest } \\
\text {-High risk taking } \\
\text {-Establishing an enterprise } \\
\text {-Enacting traditional 'ready to } \\
\text { wear' business models. }\end{array}$ \\
\hline
\end{tabular}


Table 3. Cont.

\begin{tabular}{|c|c|c|c|c|c|}
\hline Role identity & Inventor/Developer & Inventor/Founder/Developer & Developer & Inventor/Developer & Developer \\
\hline Opportunity development & $\begin{array}{l}\text {-Enacting new and innovative } \\
\text { business models with a focus } \\
\text { on wider community and } \\
\text { society level impacts. } \\
\text {-Scientific novelty and } \\
\text { science-based decision } \\
\text { making in new } \\
\text { product/service } \\
\text { development. } \\
\text {-Calculated risk taking } \\
\text {-Establishing an enterprise } \\
\text {-for more community and } \\
\text { societal impacts. } \\
\text {-Commercializing and } \\
\text { exploiting an opportunity for } \\
\text { community and societal } \\
\text { value. } \\
\text {-Sustaining growth-based on } \\
\text { technological and market } \\
\text { aspects-e.g., R \& D and } \\
\text { market partnerships. } \\
\text {-R \& D based product/service } \\
\text { improvements and } \\
\text { upgrading. } \\
\text {-Product/service diversity } \\
\text { and complementarities. } \\
\text {-Expanding to new local } \\
\text { markets. }\end{array}$ & $\begin{array}{l}\text {-Enacting new and innovative } \\
\text { business models with a focus } \\
\text { on wider community and } \\
\text { society level impacts. } \\
\text {-Scientific novelty and } \\
\text { science-based decision } \\
\text { making in new } \\
\text { products/services } \\
\text { development. } \\
\text {-Establishing multiple } \\
\text { enterprises for more } \\
\text { community and societal } \\
\text { impacts. } \\
\text {-Commercializing and } \\
\text { exploiting multiple } \\
\text { opportunities for community } \\
\text { and societal value. } \\
\text {-Sustaining growth-based on } \\
\text { technological and market } \\
\text { aspects-e.g., R \& D and } \\
\text { market partnerships. } \\
\text {-R \& D based product/service } \\
\text { improvements and } \\
\text { upgrading. } \\
\text {-Technology (solution) and } \\
\text { market driven growth. } \\
\text {-Product diversity/service. } \\
\text {-Expanding to new local } \\
\text { markets. }\end{array}$ & $\begin{array}{l}\text {-Establishing an enterprise } \\
\text { with more environmental and } \\
\text { societal impacts. } \\
\text {-Commercializing and } \\
\text { exploiting an opportunity for } \\
\text { community and societal } \\
\text { value. } \\
\text {-Enacting traditional 'ready to } \\
\text { wear' business models. } \\
\text {-Expanding to new local } \\
\text { markets } \\
\text {-Sustaining growth based on } \\
\text { market aspects for more } \\
\text { environmental and societal } \\
\text { impacts (business as a means } \\
\text { for positive environmental } \\
\text { impacts)-e.g., market } \\
\text { partnerships. }\end{array}$ & $\begin{array}{l}\text {-Commercializing and } \\
\text { exploiting an opportunity for } \\
\text { private, economic } \\
\text { self-interest. } \\
\text {-Scientific novelty in new } \\
\text { product/service } \\
\text { development. } \\
\text {-* R \& D and market } \\
\text { partnerships } \\
\text {-Establishing an enterprise } \\
\text {-Enacting traditional 'ready to } \\
\text { wear' business models. } \\
\text {-R \& D based product/service } \\
\text { development. } \\
\text {-Sustaining growth based on } \\
\text { technology and market } \\
\text { aspects-R \& D and market } \\
\text { partnerships. } \\
\text {-Expanding to new local and } \\
\text { international markets. }\end{array}$ & $\begin{array}{l}\text {-Commercializing and } \\
\text { exploiting an opportunity for } \\
\text { private, economic self-interest } \\
\text {-High risk taking } \\
\text {-Establishing an enterprise } \\
\text {-Enacting traditional 'ready to } \\
\text { wear' business models. } \\
\text {-Market driven growth } \\
\text {-Expanding to new local } \\
\text { markets }\end{array}$ \\
\hline
\end{tabular}


Table 3. Cont

\begin{tabular}{|c|c|c|c|c|c|}
\hline Role identity & Inventor/Developer & Inventor/Founder/Developer & Developer & Inventor/Developer & Developer \\
\hline Opportunity scaling & $\begin{array}{l}\text {-Sustaining growth-based on } \\
\text { technological and market } \\
\text { aspects-e.g., R \& D and } \\
\text { market partnerships. } \\
\text {-R \& D based product/service } \\
\text { improvements and } \\
\text { upgrading. } \\
\text {-Product/service diversity } \\
\text { and complementarities. } \\
\text {-Expanding to new local } \\
\text { markets. }\end{array}$ & $\begin{array}{l}\text {-Sustaining growth-based on } \\
\text { technological and market } \\
\text { aspects-e.g., R \& D and } \\
\text { market partnerships. } \\
\text {-R \& D based product/service } \\
\text { improvements and } \\
\text { upgrading. } \\
\text {-Technology (solution) and } \\
\text { market driven growth. } \\
\text {-Product diversity/service. } \\
\text {-Expanding to new local } \\
\text { markets. }\end{array}$ & $\begin{array}{l}\text {-Expanding to new local } \\
\text { markets } \\
\text {-Sustaining growth based on } \\
\text { market aspects for more } \\
\text { environmental and societal } \\
\text { impacts (business as a means } \\
\text { for positive environmental } \\
\text { impacts)-e.g., market } \\
\text { partnerships. }\end{array}$ & $\begin{array}{l}\text {-R \& D based } \\
\text { product/service } \\
\text { development. } \\
\text {-Sustaining growth based on } \\
\text { technology and market } \\
\text { aspects-R \& D and market } \\
\text { partnerships. } \\
\text {-Expanding to new local and } \\
\text { international markets. }\end{array}$ & $\begin{array}{l}\text {-Market driven growth } \\
\text {-Expanding to new local } \\
\text { markets }\end{array}$ \\
\hline
\end{tabular}

* Research \& Development. 


\subsubsection{Opportunity Recognition}

The analysis reveals differences in opportunity recognition based on an individual's social identity and the role identity that one adopts. As highlighted earlier, the respondents in the study were categorized into two groups based on social identity characteristics or identity that is more saturated, from which they derive self-worth as they execute activities leading to enterprise creation. The first category is made up of five respondents with identity profiles that included both communitarian (C) and missionary (M) characteristics in each single identity dimension; mostly the frame of reference and basic social motivation. The other category consists of two respondents with pure Darwinian identity profiles in all dimensions. To further apply known role identities, the respondents were finally clustered into five subgroups that consider behavioral differences based on both social and role identity profiles (see Table 3 , above).

Individuals whose basic social motivation connotes a combination of communitarian and missionary social identity characteristics while at the same time possessing multiple salient (inventor, founder, and developer) role identities derive self-worth from coming up with multiple new ideas that are a result of identified changes in local natural and communal environments. As a result, their new ideas for product or service development are aimed at solving identified environmental and societal problems in a community and or the society at large. For example, Oscar explained how he recognized opportunities to establish multiple enterprises: "I am the founder of Green Con. Green Con is an enterprise that I started off in the year 2000 and it came as the result I'm a researcher. Yes. I'm a serious researcher. I wear many caps. I'm a serial entrepreneur. I was doing research in plastics. We got a dump site not too far away called Dandora. It's the largest dump site in Nairobi. So, I did my research, gave it to my principal but then something struck me as a scientist. Obviously, Dandora is not the best life, it is not the best place to be. It's very huge, with all the wrong things environmentally and socially happening there. So, I realized that there's a lot of biodegradation at the dumpsite. And when that came in my mind then I thought I could generate power from there because they dump everything including biomass. So, I saw a lot of biodegradation and at that time, Kenya was going through a very difficult time of power shortages, so we were having power rationing. So, I thought widely that maybe I could generate power and distribute to the community around. That is the idea behind Green Con." Respondents such as Oscar, whose social identity is a hybrid of the communitarian and missionary, exhibited similar behavior to respondents like Sam and Don, whose social identities are also a hybrid of the communitarian and missionary, while deeply ingrained in inventor and developer role identities. The only difference is that the former recognized multiple opportunities, for purposes of developing them into multiple enterprises, due to the salient founder role identity, while the later recognized and focused attention on a single opportunity.

Individuals with salient communitarian and missionary social identities and deeply entrenched developer role identity similarly attend to changes in the local natural and communal environment to come up with a business idea aimed at solving identified environmental and or social problems [95]. The idea might not necessarily lead to totally new products or services, but could lead to adaptation of already existing products, services, or practices to a completely new context. Melvin, whose identity suits this category, expressed the following in line with opportunity recognition, "Over time, what we noticed is that waste that we used to collect from residents, when we dispose it at the disposal site, it could accumulate due to non-biodegradable waste like plastics. So, we started researching on how we could solve this problem and we found a company, in Hong Kong, that was crashing glass and using the glass sand as a component to make building blocks and they had done it for like 20 years, and we were like, 'So why do we need to re-invent the wheel, the wheel is already there. Someone has already done it.' So, we started to cultivate a relationship with this company and that's how we ended up importing from them, the technology to convert plastic and glass waste into building tiles." 
Another key behavioral difference in opportunity recognition could be observed amongst individuals with salient Darwinian social identity but with different salient role identities. Individuals with pure Darwinian social identity characteristics who also had salient inventor and developer role identities were attuned to market and information gaps as they recognized opportunities that led to the establishment of an enterprise focused on personal, economic self-interests. However, if the individual adopted a salient inventor role, they recognized opportunities for the development of new products or services based on technological novelty and informed by research and development. On the other hand, a Darwinian with salient developer role identity is equally attuned to market and information gaps, and opportunities recognized are not "other," related. In this case, they strive to establish a business for personal, economic self-interests. For example, Jan explained that his opportunity recognition was through personal product design challenges that he faced while designing electrical gadgets for personal use at home, "it started just as a business here in our home. We were making systems for companies, like motion sensors, circuit boards, and security systems. So, with that, we had a lot of challenges when it came to the final design of the products and we started researching on 3D printing and the first machine that we made was made from steel. It was just a very basic machine".

It is apparent from the analysis that individuals usually attend to identity-relevant cues in the natural and communal environment and in markets, which determine the nature and form of an opportunity that the individual develops into a business.

\subsubsection{Opportunity Development and Scaling}

Entrepreneurs pursue opportunities that are identity relevant. Individual behavior during opportunity development and scaling therefore varies based on salient social and role identities. The analysis shows that respondents with hybrid characteristics of the communitarian and missionary social identities and deeply entrenched inventor and developer role identities developed and scaled opportunities through transforming their new business ideas into new products or services that are meant to solve identified environmental and societal problems. Through their salient inventor and developer role identities, these individuals focused attention on technological aspects of the enterprise as well as activities that made them successfully deliver their products and services on the market, foster adoption to advance interests of the community and the wider society. Evidence from the analysis shows that these respondents established their businesses, commercialized, and exploited opportunities to create more value for the community and the society. They focused on scientific novelty, while making research-based decisions in new product and service development, for example: "we came up with the way we are burning currently, it saves up to $95 \%$ of the emissions that would have otherwise been released. So, we hold the emissions as carbon, but we are working on a technology that will allow us to reduce that one to zero emission. We did some test pilot with MIT and it was very successful, because we were able to get about $20 \mathrm{~kg}$ in one hour. [laughs] I guess that sounds small, but in terms of research that was a big milestone. So, we anticipate, and now we are making a bigger version of it. So, hoping that, by either end of the year or early next year we will have a technology with zero smoke. Yeah! Because we must ensure that it is made fast in the lab and it functions before, we can think of implementing it on the ground."-[Sam].

As a result of the focus on scientific novelty, respondents with hybrid social identities and deep-rooted inventor and developer roles, initiated research and development partnerships with both local and international research institutions for product and process development and improvements. Moreover, to successfully bring their new inventions to customers, they initiated marketplace partnerships with knowledgeable individuals and organizations from marketplaces. Market partnerships were regarded as important for wider community and societal impacts, in sustaining enterprise growth, and business model replication during opportunity scaling. Don, for example, expressed how his enterprise's approach particularly focused on community and wider societal impacts by establishing and scaling a self-sustaining enterprise through partnering knowledgeable 
individuals from marketplaces: "Even when we're trying to look for how to roll out our bigger digesters in marketplaces, we want partners who would partner with us because you know your marketplace, for instance, you're from there, it's your home. We will come in with the tech side and the solutions and you manage the project on the ground. And because its income generating, there is money to be made by you, so you're gonna make sure it works. And because we're making money, because as a partner we got shares, we will make sure our side of the business works. And that to me is how we're going to solve these problems".

Respondents with communitarian and missionary social identity characteristics and salient inventor and developer role identities derive self-worth from successfully establishing a stable enterprise. They focus on growth driven by technological innovation and the market, developing new products and services that induce positive societal and environmental change. Consequently, they enact new and innovative business models that foster innovation, market expansion, and product and service diversity. In line with this, Don further emphasized: "We have a model that we are rolling out. We're branding it 'trash-to-cash.' It's focused on achieving zero waste at landfill. We want to render waste disposal sites obsolete by recycling at source, every waste generated. So, not taking anything to landfill. All of the organic goes into the digester." The behavior of one respondent with salient founder role identity and all other identities, like the ones just presented, turned out to be the same in opportunity development and scaling. The only difference observed is that the salience of a founder role means that the individual derives self-worth in pursuing, developing, and scaling multiple enterprises, for example, "We started commercial production of it with the patent, local and international, yeah! Plastic, biomass, power production, water purification, agro, consultancy, medical, you know, all these enterprises! So, to me waste is not waste, waste is a resource. We are in fertilizer, we are in plastic, we are in charcoal briquettes, we are in energy production, and we are in jewelry and we are in water. But they ran as different entities. The only common person here is Oscar. Are you getting me? [ . . ]. I mean, I've got numerous innovations, all these organizations, all the 16 organizations I have are all innovations (laughs). That's how invention comes in then, I need to commercialize. That's what it turns out to be." [Oscar].

A hybrid communitarian and missionary with salient developer role, establishes and scales an enterprise with more societal and environmental impacts. Commercialization, exploitation, and expansion of an opportunity is premised on the fact that this type of an individual derives self-worth from using business as a means for making societal and environmental impact. The analysis shows that respondents exhibiting such identity traits adopt traditional "ready to wear" business models as they are not willing to take greater risk in trying new models. Their focus is on creating market value out of which they would create more environmental and social impacts. Many of their strategies are deployed to create and grow markets through, for example, boosting product sells, attracting and reaching out to more customers, market partnerships, and establishing trust-based relationships with communities: "I'm that kind of entrepreneur who wants to make sure my business succeeds in the market and through that I make both environmental and social impact"-[Melvin]. Development and scaling of an opportunity through research and development and a focus on creating and expanding markets was also observable for respondents exhibiting Darwinian characteristics while possessing inventor and developer salient role identities. For individuals with these identity profiles, self-worth is derived from successfully establishing an enterprise that offers new products and services aimed at creating personal wealth. They emphasize R\&D in new product development, market partnerships to penetrate new and unfamiliar markets, and adopt traditional business models: "We're working with investors. We were able to bring people who already know and understand the market and so we are able to fasten our production and to relate well with the clients".

Moreover, relative to respondents with other salient social and role identities, respondents with a Darwinian identity profile and heavily entrenched developer role identity 
focused more on market driven growth by undertaking various market activities, for example, expanding to new markets, attracting and recruiting new customers, initiating product distributor contracts, and remaining competitive. Relative to technological aspects, the respondents with Darwinian social identity and developer role identity profiles focused on market growth activities to increase profit margins, thus achieving their personal economic self-interests: "Okay, the truth is, when I started MB Energy, I knew it was a good business, it was viable, it was profitable. You can replicate this as you have seen, it is nothing complicated. So, it has shown its fruits, it is a business with potential."-[Gregory]. Through the themes that emerged in the data analysis, an identity-based process model sustainable entrepreneurship at the BOP was developed. Figure 1 below shows the identity-based process model of sustainable enterprise creation (opportunity recognition, opportunity development and opportunity scaling).

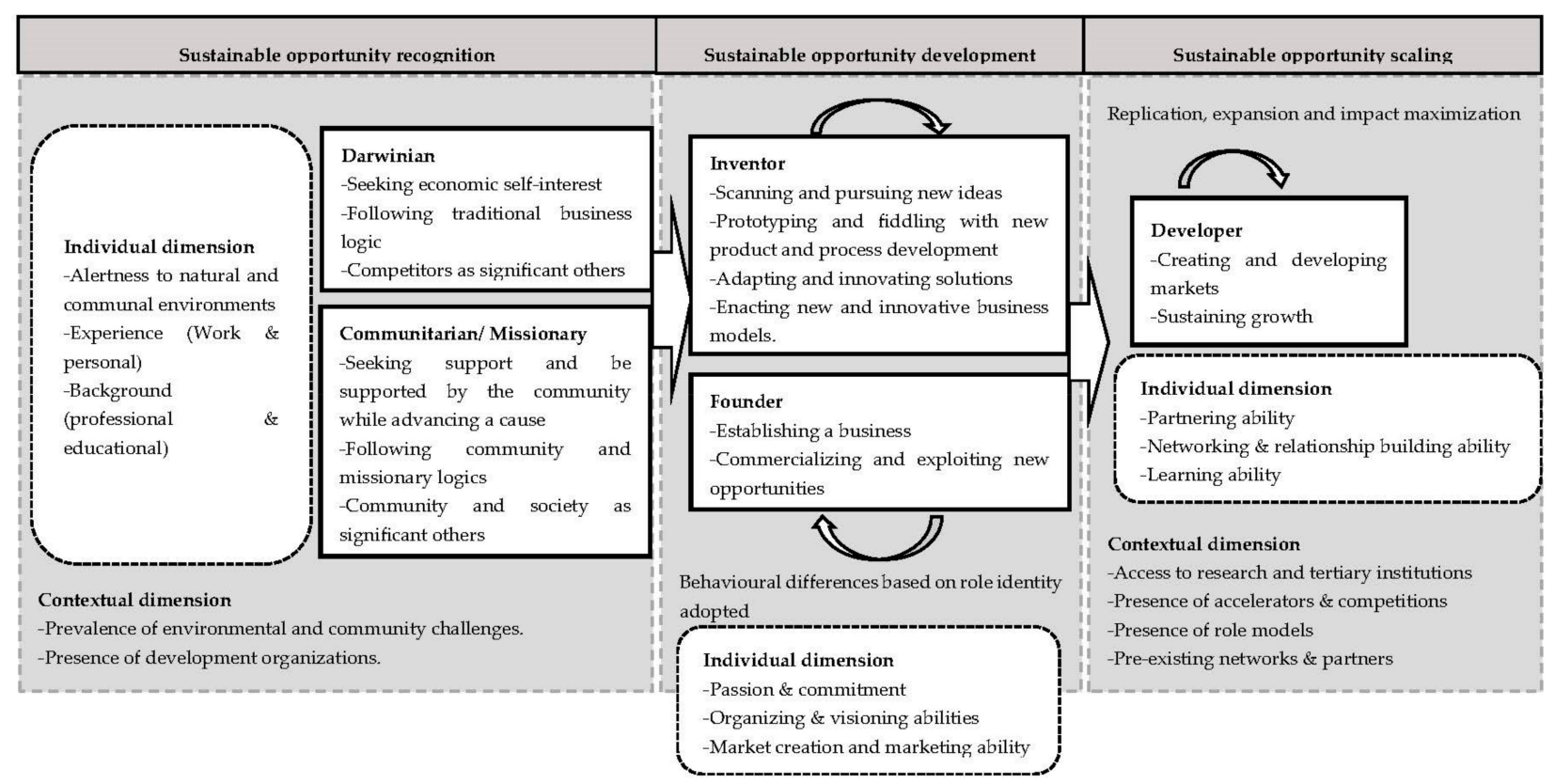

Figure 1. Identity-based process model of sustainable entrepreneurship.

The analysis of the cases enabled to understand the identity profiles of BOP entrepreneurs engaged in entrepreneurial activities focusing on issues related to sustainability. Additionally, though evidence from the cases, the identity based behavioral differences that existed amongst the respondents were illuminated.

\section{Discussion}

The study was guided by the overarching research questions of how founders of sustainable enterprises at the BOP identified themselves and how these identities influenced the enterprise creation process. To illuminate these research questions, the data was first analyzed in light of Fauchart and Gruber's social identity typologies and Cardon et al.'s role identities [53]. Next, role-relevant behaviors in the enterprise creation process were examined. The findings of this study make several nuanced contributions to sustainable entrepreneurship theory through the context of BOP sustainable entrepreneurship. First, the analysis of the data revealed that the existing social identity typologies and role identities can be applied to BOP actors to understand what it means to be entrepreneurs engaged in activities focused on sustainability issues and the self-worth they seek to obtain from becoming founders in such contexts. Thus, more light is shed on the identity profiles of BOP sustainable entrepreneurs. The findings of this study revealed that, due to their multiple frames of reference and basic social motivations, respondents are heterogenous and could be assigned into two groups based on their social identity salience and five 
subgroups based on their role identity salience (see Table 3). These findings are in line with findings of other scholars [24,33], who established that entrepreneurial social identities usually amount to different levels of saturation of the three social identity types, while Stryker [1] expressed that actors may hold multiple role identities that align with different logics. In this study, respondents with strong saturation of both communitarian and missionary identity types derive self-worth from being able to provide products and services that they perceive as truly beneficial to the community that they are a part of and the society at large. As their main goal would be to serve the community and society, entrepreneurs in this study engage in activities that they believe would make them achieve this goal [96]. Through drawing from multiple frames of reference, the entrepreneurs initially focused on serving local communities, and when their business models succeed, they replicate and expand to the level of society. This implies that there are social identity changes from communitarian in opportunity recognition and development to hybrid communitarian/missionary in opportunity scaling.

Individuals with salient communitarian and missionary identities considered as core to the entrepreneurial process their engagement in activities that supported lives and aspirations of community and societal members, for example, offering business training and mentorship, community organizing and formalization, and skills transfer to create micro-entrepreneurs in the form of waste suppliers. This is in line with previous study implications that communitarian entrepreneurs derive self-worth primarily from being able to offer products and services that help in advancing their communities and thus view their community as their primary frame of reference [24]. In addition, this study shows that entrepreneurs of the communitarian and missionary type also view the environment as their primary frame of reference and evaluate themselves based on the efficacy of their solution to an identified environmental problem and therefore endeavor to provide products and services that solve environmental challenges, resulting in their being able to provide triple bottom line solutions. Nevertheless, the same entrepreneurs also exhibited some Darwinian attributes such as viewing their competitors and their professional field as the primary frame of reference in the social space. Some highlighted being professionals who belong to a professional group [33]. Moreover, Darwinian entrepreneurs pursued the goal of making profit while successfully remaining competitive. They followed traditional business logic and behave in ways congruent with traditional business management $[35,96]$.

On the other hand, the role identities of Cardon et al.'s could be observed amongst sustainable entrepreneurs at the BOP. The findings of the study showed that some of the respondents have multiple salient role identities, while others have a single role identity. Interestingly, all respondents expressed the ambition to grow their enterprises, implying that the developer role is salient across all cases. However, their behavior in enterprise development and scaling varied depending on other role identities that are salient. For example, respondents with inventor and developer role identities focused on establishing a stable enterprise through working on their new technologies and growing markets for their products and services. Thus, in developing and scaling their opportunities, emphasis was on aspects such as R\&D, R\&D partnerships, and market partnerships for fostering product adoption to increase sales and expand markets. Gruber \& MacMillan pointed out that role identities explain the existing behavioral differences among Darwinians, communitarians, and missionaries. Salient role identities are associated with knowledge useful in opportunity recognition and development [24]. The respondents of the study recognized, and developed opportunities based on their salient role identities that are related to prior entrepreneurial work and personal life experiences. Knowledge and competences in particular domains are key in opportunity recognition and development and salient roles are associated with knowledge and competences of specific domains [36,95]. As highlighted earlier, social and role identities influenced scaling up of opportunities, with some respondents assuming roles that they considered key in achieving their goals. More importantly, this study has led us into important insights on sustainable entrepreneurship, which would not possibly have been revealed without considering the social identities of founders. The 
findings point to the presence of sustainable entrepreneurs who derive self-worth from pursuing the traditional for-profit business logic. Even though they are motivated by both, for example economic self-interest and advancing a cause, Darwinian sustainable entrepreneurs search for market gaps, design and establish an enterprise focused on profit, and work on growing the enterprise to derive personal satisfaction.

The findings of the study present key practical implications. First, as opposed to the mainstream assumption that BOP entrepreneurs engage in entrepreneurial activities driven by necessity, the findings of this study establish that BOP entrepreneurs are also driven by the need to solve social and environmental problems. The foregoing finding entails that BOP entrepreneurs derive self-worth from becoming founders of enterprises that are focused on advancing the welfare of known and unknown significant others. Therefore, government programs in developing countries that seek to advance sustainable development through entrepreneurship can engage these entrepreneurs from the perspective of their motivations and frames of reference, which would create more positive economic, social, and environmental impact in such economies. Entrepreneurs with strong saturation of the communitarian and missionary identities with deeply ingrained inventor, founder, and developer identities enact new and innovative business models that foster technological development and market linkages while engaging in activities to create enterprising communities in impoverished contexts, for example organizing community members into formalized micro-entrepreneurs, linking waste micro-entrepreneurs to health insurance and banking services. These activities boost local economies while creating spillover effects and, thus creating business environments in which they can thrive as an important source of socio-economic development. The study findings also suggest that sustainable entrepreneurial activities at BOP could be a mechanism for realizing professional aspirations by actors engaged in it. Additionally, the study findings have reflected on an important aspect of sustainable entrepreneurship that is grounded in identity. This is the need for the entrepreneurs to be "unique" (otherness) while at the same time wanting to "belong" to a certain societal category (sameness) [97]. This situation usually creates role conflict, especially when the roles for each situation are not congruent, resulting in negative emotional consequences for the entrepreneur.

\section{Intervening Individual and Contextual Dimensions}

The analysis revealed that there are several individual and contextual factors that interacted with an individual's identity profile to determine the way they recognized, developed, and scaled entrepreneurial opportunities (see Figure 1). Most of the respondents had some professional experience in both formal employment in the non-governmental organization (NGO) sector and entrepreneurship, having previously founded their own enterprises. Four of the cases had prior experience in founding their own enterprises that were not sustainability-related but mostly in line with their professional background, while in one case, the founder had previously founded a sustainability-related enterprise in the form of a community-based organization and had professional experience in the NGO and banking sectors. One respondent had no prior work or entrepreneurial experience and started his business soon after graduating from university. The data analysis shows that some founders leveraged prior work roles, and professional and personal experience to recognize and develop new opportunities. The social entrepreneurships literature supports this finding, for example Wry and York [36] highlighted that actors are more likely to recognize opportunities in areas that they are knowledgeable about.

The findings revealed that respondents with communitarian and missionary social identity characteristics recognize an opportunity by first recognizing an environmental or societal problem as a result of being alert to the natural and communal environmental changes. Thus, alertness to natural and communal environments, personal values, and beliefs turned out to be key individual dimensions that lead to opportunity recognition that is "other" related. According to Patzelt and Shepherd, individuals who recognize opportunities for sustainable development attend to natural and communal environments. 
During opportunity development, individual characteristics and abilities such as passion and persistence, marketing ability, and organizing and visioning abilities turned out to be crucial as they interact with identity to determine behavior and the scope of the enterprise. Passion and persistence are associated with salient role identities, for example Cardon et al. were able to show that passion is related to the three role identities through various mechanisms. Marketing and organizing abilities were critical as most of the products were new, hence entrepreneurs needed to create and grow markets attracting and recruiting new customers as well as recruiting and creating proper structures for value creation and delivery. Visioning ability enabled entrepreneurs to have a vision for their enterprise and lay out goals that they worked to achieve to attain the vision. In opportunity scaling, learning, partnership, network, and relationship building abilities were key as they helped entrepreneurs to learn through trial and error as in some cases, the outcome of the opportunity development process was not known. Partnership and relationship building abilities acted as a platform for entrepreneurs to establish connections with other stakeholders in order to access critical resources, for example, information, human, financial, emotional, as well as feedback during opportunity scaling and business model replication [98].

This study also noted certain contextual factors that are relevant in the recognition, development, and scaling of sustainability-related opportunities. The prevalence of natural and social challenges, for example, was critical in the recognition of opportunities that are other-focused. Entrepreneurs derive self-worth from recognizing and pursuing opportunities that solve environmental and social challenges. The presence of development agencies and research institutions was key in creating R\&D partnerships during opportunity scaling. Entrepreneurs at the BOP lack some of the knowledge and expertise critical in product development, thus partnerships with local and international research institutions and development agencies turned out to be key in the successful creation of sustainable enterprise at the BOP. More importantly, this study showed that the presence of accelerators and entrepreneurship competitions that support sustainable ideas was key in commercializing the opportunity [45]. All the respondents acknowledged the role played by the National Environment Trust Fund in supporting their enterprises through the green innovations' awards and incubation program.

\section{Conclusions}

The main objective of this study was to explore and understand BOP entrepreneurs' self-perceived identities and how these influence behaviors in sustainable enterprise creation (opportunity recognition, opportunity development and opportunity scaling). To achieve this objective, data collected from seven founders of sustainable enterprises and other key stakeholders in Kenya were qualitatively explored and analyzed. The study therefore contributes to the sustainable entrepreneurship literature. The foremost contribution is in combining sustainable entrepreneurship and identity as distinct fields of study to illuminate important aspects of sustainable entrepreneurship at the BOP. The study provides evidence of the existence of Fauchart and Gruber's social identity typologies and Cardon et al.'s the role identities. The findings of the study suggest that both social and role identities influence opportunity recognition, while role identities result in behavioral differences amongst actors with the same social identities as they develop and scale their opportunities. The study revealed that within the pure types suggested by Fauchart and Gruber [24], those entrepreneurs with different combinations of attributes of the three pure types have multiple frames of reference and basic social motivations, which play an important role in their ability to harmoniously integrate the triple bottom line goals to successfully recognize, develop, and scale opportunities.

Moreover, entrepreneurs with a strong saturation of the communitarian and missionary entrepreneurial identity underlying their motivation as founders constitute respondents who developed and scaled their opportunities, prioritizing their triple bottom line goals without shifting their identity, notwithstanding the existence of Darwinian attributes such 
as their profession and personal self as basis of self-evaluation and competition and business networks as part of the primary frames of reference. The only social identity shifts observed did not cause any mission drift but rather reinforced it, for example, shifting from communitarian to a hybrid of communitarian and missionary as the enterprise grows, and the business model succeeds. Respondents, whose opportunity recognition is preceded by recognition of either an environmental or social problem, assume a problem-solving role, which acts as a compass that directs efforts towards proffering solution to the problems. While the study by Fauchart and Gruber offers important insights on the heterogeneity of founders' social identities and how these are expressed in enterprise creation. This study provides a theoretically relevant point of departure in entrepreneurial behavior research by providing empirically grounded evidence of behavioral heterogeneity within social identity prototypes at distinct phases of the enterprise creation process based on role identities that each founder considers most meaningful and salient to their self-worth [53]. As already highlighted, this study confirms a theoretical fit of the social identity typologies by Fauchart and Gruber within the context of BOP sustainable entrepreneurial activities while at the same time highlighting the hybrid nature of such entrepreneurial activities.

The study was not done without limitations. To start, studies drawing from qualitative cases are not generalizable to populations. Second, the cases are all from the waste management sector. Even though the ways the entrepreneurs in this study developed their opportunities and scaled their enterprises were different, the single sector context may limit the potential for theoretical expositions and saturation. Last and most importantly, even though data triangulation was applied, and the respondents, who are the founders, were key decision makers in their enterprises, the study might be affected by respondent bias. However, various strategies were employed to ensure that the theorizing in this study was robust and as unbiased as possible, for example having multiple coders and discussion on codes as well as having outsiders as coders. Further studies could benefit from a longer timeframe and thus follow the respondents for a considerably longer time period to explore other important aspects of sustainable entrepreneurs at the BOP, for example, how the entrepreneurs manage to balance the sustainability-business tensions and if they maintain prioritization of the triple bottom line goals over time. Moreover, the duration of each phase (i.e., opportunity recognition, opportunity development and opportunity scaling) in the creation of the enterprises might be a critical factor that provides key insights on the role of identity in the enterprise creation process. Due to short periods of observations and data collection, this study and its findings are not able to capture the likely shifts in founders' identities due to, for example, cyclical processes, market dynamics, and general business environment factors. Thus, further studies applying a longitudinal approach would be able to divulge these shifts, their sources, and their likely consequences for identity profiles.

Author Contributions: Funding acquisition, J.M.; conceptualization, J.M., K.P., A.V. and H.S.; methodology, J.M. and A.V.; formal analysis, J.M.; writing-original draft preparation, J.M., K.P., A.V. and H.S.; writing- review and editing, J.M., K.P., A.V. and H.S. All authors have read and agreed to the published version of the manuscript.

Funding: Data collection for the data used in this research article was funded by Liikesivistysrahasto, 2019 grant round.

Institutional Review Board Statement: Not applicable.

Informed Consent Statement: Informed consent was obtained from all respondents involved in the study.

Data Availability Statement: Data presented in this study is available upon request.

Acknowledgments: The authors are indebted to comments received in an August 2019 conference from which this manuscript was iteratively developed.

Conflicts of Interest: The authors declare no conflict of interest. 
Appendix A

Table A1. Social identity dimensions developed from Fauchart and Gruber (2011).

\begin{tabular}{|c|c|c|c|c|c|c|c|}
\hline & Don & Oscar & Gregory & Jan & Melvin & Patrick & Sam \\
\hline $\begin{array}{l}\text { Frame of Refer- } \\
\text { ence/relevant } \\
\text { others }\end{array}$ & $\begin{array}{l}\text { Known Others: } \\
\text { Providing a product } \\
\text { that supports the } \\
\text { local community } \\
\text { seen as core to the } \\
\text { entrepreneurial } \\
\text { process. Increasing } \\
\text { livelihoods of local } \\
\text { communities. } \\
\text { Unknown others: } \\
\text { Demonstrating the } \\
\text { feasibility of } \\
\text { alternative practices } \\
\text { and leading by } \\
\text { example through } \\
\text { helping society. } \\
\text { Competing } \\
\text { products: being } \\
\text { distinct } \\
\text { (differentness) by } \\
\text { proving health and } \\
\text { price benefits of } \\
\text { products. }\end{array}$ & $\begin{array}{l}\text { Unknown others: } \\
\text { Demonstrating the } \\
\text { feasibility of alternative } \\
\text { social practices and } \\
\text { leading by example core } \\
\text { to the entrepreneurial } \\
\text { process, i.e., alternative } \\
\text { green building materials. } \\
\text { Known others: } \\
\text { engaging in activities } \\
\text { that benefit the } \\
\text { community. } \\
\text { Competitors: } \\
\text { Developing and offering } \\
\text { products that are distinct } \\
\text { from existing traditional } \\
\text { products considered } \\
\text { critical. }\end{array}$ & $\begin{array}{l}\text { Competitors: Being } \\
\text { different from others } \\
\text { by coming up with a } \\
\text { product distinct from } \\
\text { available } \\
\text { conventional } \\
\text { products seen as core } \\
\text { to the entrepreneurial } \\
\text { process. } \\
\text { Known others: } \\
\text { offering products } \\
\text { that support a } \\
\text { community } \\
\text { considered core to } \\
\text { the entrepreneurial } \\
\text { process. }\end{array}$ & $\begin{array}{l}\text { Competitors: being } \\
\text { distinct from others } \\
\text { by offering products } \\
\text { with competitively } \\
\text { lower prices. }\end{array}$ & $\begin{array}{l}\text { Competitors: Being } \\
\text { different from others } \\
\text { seen as core to the } \\
\text { entrepreneurial } \\
\text { process. } \\
\text { Unknown others: } \\
\text { Demonstrating that } \\
\text { alternative social } \\
\text { practices and products } \\
\text { are feasible and } \\
\text { leading by example } \\
\text { seen as core to the } \\
\text { entrepreneurial } \\
\text { process. } \\
\text { Known others: } \\
\text { offering products } \\
\text { (alternative green } \\
\text { building material) } \\
\text { products that support } \\
\text { the community seen as } \\
\text { core to the } \\
\text { entrepreneurial } \\
\text { process. }\end{array}$ & $\begin{array}{l}\text { Competitors: } \\
\text { Wanting to be } \\
\text { different from others } \\
\text { based on perceived } \\
\text { skills. } \\
\text { Known others: } \\
\text { Helping known } \\
\text { others. } \\
\text { Unknown others: } \\
\text { Doing good to } \\
\text { known others } \\
\text { (leading by example } \\
\text { seen as core to the } \\
\text { entrepreneurial } \\
\text { process). }\end{array}$ & $\begin{array}{l}\text { Known others: } \\
\text { Providing a product } \\
\text { that supports the } \\
\text { community seen as } \\
\text { core to the } \\
\text { entrepreneurial } \\
\text { process. } \\
\text { Competitors: Being } \\
\text { different from others } \\
\text { seen as core to the } \\
\text { entrepreneurial } \\
\text { process. }\end{array}$ \\
\hline
\end{tabular}


Table A1. Cont.

\begin{tabular}{|c|c|c|c|c|c|c|c|}
\hline & Don & Oscar & Gregory & Jan & Melvin & Patrick & Sam \\
\hline $\begin{array}{l}\text { Basic Social } \\
\text { Motivation }\end{array}$ & $\begin{array}{l}\text { Advancing a cause: } \\
\text { Saving trees and } \\
\text { forests through } \\
\text { creation of a } \\
\text { enterprise that } \\
\text { provides alternative } \\
\text { product to firewood } \\
\text { and charcoal. } \\
\text { Reducing pollution } \\
\text { in communal areas } \\
\text { by providing clean } \\
\text { fuel. } \\
\text { To support and be } \\
\text { supported by the } \\
\text { community through } \\
\text { business models that } \\
\text { foster income } \\
\text { generation for } \\
\text { community members } \\
\text { and profit for the } \\
\text { enterprise. }\end{array}$ & $\begin{array}{l}\text { Getting support from } \\
\text { the community while } \\
\text { offering products that } \\
\text { supports the } \\
\text { community-mutual and } \\
\text { beneficial relationships. } \\
\text { Advancing a cause: } \\
\text { Having a positive impact } \\
\text { on the market by solving } \\
\text { social challenges. } \\
\text { Inspired to address social } \\
\text { challenges, e.g affordable } \\
\text { housing and } \\
\text { employment creation. }\end{array}$ & $\begin{array}{l}\text { Self-interest: } \\
\text { Creating } \\
\text { employment for self } \\
\text { to generate personal } \\
\text { income (being own } \\
\text { boss). Family } \\
\text { pressure to do } \\
\text { something that } \\
\text { generate income. }\end{array}$ & $\begin{array}{l}\text { Self-interest: coming } \\
\text { up with own product } \\
\text { designs that are } \\
\text { attractive to } \\
\text { customers-money } \\
\text { making. }\end{array}$ & $\begin{array}{l}\text { Self-interest: } \\
\text { Enterprise creation to } \\
\text { create employment for } \\
\text { self. } \\
\text { Supporting and be } \\
\text { supported by a } \\
\text { community because } \\
\text { of mutually beneficial } \\
\text { relationships. } \\
\text { Advancing a cause: } \\
\text { Enterprise creation } \\
\text { supports individual's } \\
\text { ambition to advance a } \\
\text { cause-environmental } \\
\text { management. }\end{array}$ & $\begin{array}{l}\text { Advancing a cause: } \\
\text { Providing an } \\
\text { alternative to people } \\
\text { to conserve the } \\
\text { environment. } \\
\text { Support and being } \\
\text { supported by the } \\
\text { community by } \\
\text { providing an } \\
\text { alternative source of } \\
\text { energy while making } \\
\text { profit and engaging } \\
\text { in activities that } \\
\text { support the } \\
\text { community. }\end{array}$ & $\begin{array}{l}\text { Support and be } \\
\text { supported by a } \\
\text { community: } \\
\text { Supporting a } \\
\text { community by } \\
\text { providing a product } \\
\text { that solves a } \\
\text { community challenge } \\
\text { and getting support } \\
\text { from the community } \\
\text { to grow the } \\
\text { enterprise-mutually } \\
\text { beneficial } \\
\text { relationships. } \\
\text { Advancing a cause: } \\
\text { enterprise creation } \\
\text { supports one's } \\
\text { political vision and } \\
\text { ambition to advance } \\
\text { a cause-social. }\end{array}$ \\
\hline $\begin{array}{c}\text { Basis of } \\
\text { Self-evaluation }\end{array}$ & $\begin{array}{l}\text { Socioenvironmental } \\
\text { authenticity: coming } \\
\text { up with something } \\
\text { truly useful to the } \\
\text { community as } \\
\text { perceived as critical. }\end{array}$ & $\begin{array}{l}\text { Socially and } \\
\text { environmentally } \\
\text { responsible behavior: } \\
\text { Contributing to a just } \\
\text { social order through } \\
\text { environmentally } \\
\text { responsible business } \\
\text { considered core. Societal } \\
\text { transformation through } \\
\text { local solutions. } \\
\text { Authenticity: Bringing a } \\
\text { product and engaging in } \\
\text { activities truly useful to } \\
\text { the community } \\
\text { perceived as critical. }\end{array}$ & $\begin{array}{l}\text { Business related } \\
\text { competences: Being } \\
\text { able to successfully } \\
\text { establish an } \\
\text { enterprise that brings } \\
\text { income is considered } \\
\text { core to the } \\
\text { entrepreneurial } \\
\text { process. }\end{array}$ & $\begin{array}{l}\text { Professionalism: } \\
\text { professionally } \\
\text { designed and } \\
\text { attractive product. } \\
\text { Being able to } \\
\text { professionally design } \\
\text { and develop } \\
\text { products attractive to } \\
\text { customers is } \\
\text { considered core to } \\
\text { the entrepreneurial } \\
\text { process. 'Making a } \\
\text { product that can sell'. }\end{array}$ & $\begin{array}{l}\text { Authenticity: bringing } \\
\text { products and engaging } \\
\text { in activities truly useful } \\
\text { to the community is } \\
\text { considered core to the } \\
\text { entrepreneurial } \\
\text { process. } \\
\text { Responsible behavior: } \\
\text { Contributing to a better } \\
\text { world through } \\
\text { business-responsible } \\
\text { people do act. }\end{array}$ & $\begin{array}{l}\text { Authenticity: } \\
\text { Bringing a product } \\
\text { and engaging in } \\
\text { activities truly useful } \\
\text { to the community } \\
\text { and environment } \\
\text { considered critical. }\end{array}$ & $\begin{array}{l}\text { Responsible } \\
\text { behavior: } \\
\text { contributing to a } \\
\text { better world through } \\
\text { business perceived as } \\
\text { critical-truly } \\
\text { responsible people } \\
\text { do act. } \\
\text { Authenticity: } \\
\text { Bringing a product } \\
\text { and engaging in } \\
\text { activities truly useful } \\
\text { to the community } \\
\text { perceived as critical. }\end{array}$ \\
\hline
\end{tabular}




\section{Appendix B}

Table A2. Role identity structure developed from Cardon et al. (2009).

Aggregate Dimension

Inventor scanning for and pursuing new ideas
Quote

So, one of the focuses we're doing is on invasive plant species. But we're looking at them as resources, you know, don't condemn them! Look at why they are there and then manage them and stop them ... [l, now we look at, why is it there? Then what is it doing? Where is it getting its nutrients from? Because from the digester, we're gonna get back the nutrients. Uh, food security in the world is one of the leading global sustainable goals. Africa being one of the focus, Yeah. "-[D]. "I used to make my own gadgets for a company called (N) Engineering. So, with that, I realized that also the same clients needed security systems in their homes. So, we started to make kits for security, like motion sensors, GSM modules, but I realized it was a small market, and the other biggest problem I had also, was the enclosure for all those circuits i was making-how do i make the end product and it can sell? So, with 3D printing, now like, four years later we're now making kits which are standardized. So, we're able to play around with a lot of designs in the software and we prototype the designs."-[J]. "Later, I moved on and I paid a visit to this area and I saw a lot of rice husks, and I asked myself, 'What do they do with the rice husks?' So, at that point, I realized, 'Nothing.' And I was like, 'Seriously! That is a wasted resource; you know, these things should do something.' So, I did some research and I started working on briquettes. And I realized they have a lot of ash content. The rice husks have a lot of ash, so, they cannot be used, more so, for, commercialization as pure. So, I said, 'Okay, let me see what else can I do!' I started making mosquito coils and we realized they were not performing well, so we realized this might not be very feasible, and that time is when we thought, 'What if,' just 'what if we take this

back to the farm, what would happen?'"-[S]. "We look at where there exists an opportunity. The opportunities exist, I find that I can make garbage into housing material. From a medical perspective if I find that firewood causes the largest number of respiratory illnesses, I came up with a briquette that does not emit smoke. That's how enterprise [A] was established. If I came up with how to recycle aluminum, I came up with how to recycle metal into jewelry ... [] we look at African solutions. Yeah, we recycle plastic."-[O]. 
Table A2. Cont.

"Green Con is an enterprise that I started off in the year 2000 and it came as the result I'm a researcher. Yes. I'm a serious researcher. All, these companies I run are out of research and product development. So, I have been on this for some time-20 years now. Green Con was born in the year 2000 from my research. I was doing research in plastics ... [O]. "Dr. Oscar began researching on plastic waste management in the year 2000 but had to wait for more than ten years to accumulate all the capital to actualize his idea.'- [K24 TV]." We came up with the way we are burning currently, it saves up to $95 \%$ of the emissions that would have otherwise been released. So, we hold them, yeah, as carbon. But we are working on a technology that will allow us to reduce that one to zero emission." "we have partnered with the research organizations, we have partnered with Miadi, which majorly supplies much of the information. We did, uh, test pilot with MIT and it was very successful because we were able to get about $20 \mathrm{~kg}$ in one hour (laughs). I guess that's small it sounds small but in terms of research that is a big milestone and now we are making a bigger version of it. So, hoping that,

Prototyping and fiddling with new product and process development by either end of the year or early next year we will have a technology with, zero smoke. Yeah! because you must ensure that it must be made fast in the lab and it functions before, we can think of implementing it on the ground. So right now, we have partnered with two universities, we have MIT and University of

California, Berkeley to ensure that we deliver this as soon as possible. Yeah, because we are developing new products every day. We are improving on our products every day and these guys must do the efficacy tests, because this is technology development. And in terms of improving the technology, you know, everyday things are changing."-[S]. "We prototyped for about five years, constantly breaking the system down,

building it up, changing the interior and working on that until we solved that problem."-[D]. "You see, sometimes, I can say, within the idea creation to prototyping some of these things you can put your sweat equity into it. Like, for example, what we were doing. But sometimes you need money, for example, to access a laboratory that is going to test these prototypes for you and give you the specifications and, you know, actually, you try and come up with ideas, because that time we were not sure whether to make a roofing tile or to make a paving slab or what?"-[S]. 
Table A2. Cont.

Aggregate Dimension
Illustrative Themes

Adapting and innovating for solutions

\section{Quote}

"In Kenya, our biggest challenge, one of the biggest challenge other than universal healthcare is affordable housing. Now, we've gone beyond just this, and I've invented many others than what you see in Green Con And we moved on to invent other materials and started other companies. Fine, a lot of people know me for

Green Con, but we've got 16 other companies. You get it. Yes." A lot of people want to partner with me,

because there's a new solution in waste management, in water recycling, in biomass-we are the owners of $X$ Energy too. $X$ energy recycles biomass into industrial and household charcoal briquettes. I also propagate fish somewhere, which takes care of food security. Are you seeing it? So, it's a whole 360 degree turn on what was a problem to become something that is a resource. That's how I work. "That's what I do. It's about innovation, it's about social transformation, it's about what we call the impact of social entrepreneurship and it's about where we want to go to as a continent. You see, when you come up with your innovation, look at what positive impact will it have on the market, 'what is Kenya's housing challenge? -cost, quality, durability. And does it create employment? -yes! Along the value chain." "Innovative firms such as Q Agritech will be

key in contributing to a sustainable agribusiness development as we also race against time towards

environmental conservation"- [K24 TV]. "So that is what innovation can do, but all this has societal

challenges. Affordable African solution, my solution is local Kenyan solution."-[O] "So, we're developing hot water systems now to heat the digesters. I think the problem in developing countries is that we want to make everything ... [] there's no point in reinventing the wheels wholly. You can adapt this pump. This pump is designed for high pressure car washes. So, I want to use it for the solar pumps. It's made for something else, but you can use it for something, very different. It's gonna make a huge difference somewhere else. It's good because we are rewriting the books on biogas to a large degree. We are coming up with something different from the conventional biogas and, we're demonstrating the conventional one is actually bad."-[S]. 
Table A2. Cont.

Aggregate Dimension
Illustrative Themes

Enacting new and innovative business models

\section{Quote}

"That's one area that bring the kind of business we are in, we need to help them. So, we will, certainly! and then on the side of the agriculture, agricultural people we're trying to reduce, post-harvest losses by providing enough energy to value-add to their farm projects. Um, as a waste management, as I said, from the circular economy system within municipalities. Uh whether invasive species like in Lake Victoria using water hyacinth, uh, you know, controlling invasive species. Then there's domestic systems. So, we've such a wide range of products and then we've got the things that go on the tail end of it, the how to use the fertilizer the hot water systems that also compliment. Solar, electric, solar PV also compliments the biogas. So, a lot of the gadgetry runs in combination-energy, biogas and solar. So, you know, I always advise people, you know, "if you're gonna do that and you think that's gonna work, do both." Don't compromise one with the other. You know? But do both, don't put all your eggs in one basket. Because you know, if that basket breaks, you need something to lean on."-[D]. "So, we make fencing posts. We make Lumber plans, we make driveway blocks, uh, as alternative materials to the formal construction. The challenges that we are addressing are basically four-fold; one is that we have in managing waste. Two, we have created employment within the value chain because i got like about 700 collectors who we clustered into community-based organizations of between 10 and 20. And we train them on how to segregate, and how to pre-process the plastic. There are cases where we lease them some machinery, the basic machinery and it has worked well. It's a model that's unique. But we're looking to be an alternative building material supplier, the market has accepted it."-[O]. "We have four lines of products. We have the planting, the original biochar, that is plain, and we call it the acid amender, acidic soil amender. we have a planting fertilizer; we have a top-dressing fertilizer and we have a foliar. so, those are the four lines that we have for the product, so far. What we are doing is co-own the enterprises-own the business together with youths in communities. Yeah. So, at the end of the day, we wan wherever we go and open a new plant, we get a minimum share. We don't want a majority share. We get a minimum share, we train them, and then we work together as a team, and that way we're guaranteed that our cash will be well secured."-[S]. 
Table A2. Cont.

\section{Aggregate Dimension}

Creating and developing markets

\section{Quote}

"Another case is you could go somewhere; people do not know what you're talking about. You must introduce them to the product, 'this is this'. That's another challenge especially on the side of briquettes. What is better? Why, are you telling me to use briquettes other than charcoal?_-such things! ... [] I moved from selling to the local ordinary people who were buying the briquettes at that time, because they were stil buying them in small quantities. I moved on, looking for factories, those hotels that operate boilers. From there, I realized the demand was so high. I could not even be able to supply or to exhaust the market."-[P]. "Apart from the technical, there's also, basically the market, we had to sensitize people about 3D printing,

because most of the people we meet think a 3D printer is a traditional paper. So, we must show this

physically to the clients or to the people who are coming to exhibitions. Because most people don't even know a 3D printer exist. And those who already know 3D printing exist, they only see it in YouTube or just in pictures. So, we do a lot of conferences. We also do speeches and we present our business model. We prepare presentations when it comes to forums. A lot of trainings and publications to create the knowledge about our 3D printers."-[J]. " ... [] after buying that electric machine i was able to produce more. But now the customers were not there, because now the production is more, you have more bags, so I still had to do more marketing, people had never seen briquettes. But one year down the lane, after I struggled, everything opened. I was able to make good sales. So eventually, I was able to capture many clients, many hotels. Right now, there are many hotels as my customers."-[G]. "We're looking to be an alternative building materia

supplier. The market has accepted it. So, a lot of what I engage in are negotiations, marketing, telling government and NGOs. When it comes to implementing that strategy in terms of corporate strategies with market linkages and partnerships it's me, you get it? If it is selling, it's my linkages because I see and meet people in many capacities. In church, I'm a pastor, in schools or universities, I'm a lecturer, then entrepreneurially, I sit in a number of entrepreneurial organizations."-[O]. 
Table A2. Cont.

\section{Aggregate Dimension}

Illustrative Themes

Sustaining enterprise growth

"We're not big. We're expanding. We are growing ... [] you'd have to have multiple of these things and they're expensive to put in, they're not cheap because of the materials we use. They cost, so you need to earn enough to organically grow without going down the road of looking for donors and sponsorships ... []. So, we hope to have them [biogas digesters] all over the place and they will be ours and we will be generating

income from them and combining that to put more all over the place and continue growing like that. Sustainability is ownership! We've got to own what we do. Many people have said to us, 'you're doing such philanthropic work, you're more of a social enterprise. Why didn't you become an NGO?' I said, 'because

then we would just become beggars.' We would be constantly asking people, 'give us money.' So, our approach is completely the opposite."-[D]. "So, what I want is a situation where you can't avoid me when building locally or internationally-you can't avoid me when building. Then I'll feel safe. Then I would have grown it from where it was to the multimillion-dollar business it is today. My vision is to see a brand owned by Z ltd, the group of companies, go continental not just Kenya alone, not just Nairobi alone, but across Africa. That is why I diversify. If you know where to get your money from and you've got what it takes to grow it, then you can virtually own anything. The challenge is you might have an idea of what to do, but you do not know how to grow it or where to get the money to invest in it. I run my business fully and that's how I've grown the empire I have now."-[O]. "To meet this growing demand of their products, Green Con needed to increase the capacity of their equipment, which by now has recycled more than 700 tons of plastic from

landfill."-[K24 News]. "Before i answer that, you know there is one saying that people say, they say it in

Kiswahili; 'biashara niya mtu', meaning to say; 'the business is the owner'. So, if you put passion in anything As long as you put passion and effort, it can never fail. I started with a manual machine for like three months. After saving, I was able to buy a small, electric machine. I worked with that electric machine for almost two years, then I bought the ones that you have seen here. that is when I moved to this place back in 2016."-[G].

"I wear many caps. I'm a serial entrepreneur. all, these companies I run, they're over 10. So, I embarked, after I discovered this. I did a couple of presentations and made my prototype and then decided to patent it. The patent came out, I think 10 years later in 2010, 2011. And there we are. But they are owned by the same person, because i told you I've got 16 entities. am the owner of them because I control shares in all of them. If

I sit back, there are all these companies. There is a holding company called Z company. It's a holding company. It owns very many other and social entities."-[O]. 
Table A2. Cont.

Aggregate Dimension
Illustrative Themes

Commercializing and exploiting new opportunities

\section{Quote}

"I saw an opportunity that people did not see, an opportunity that had two ways, at the same time to conserve the environment, at the same to grow a business that nobody else had done, yeah! So, it was a two-way thing. Because I knew with both ways, you are making an income, whether you're conserving an environment or you're doing a business that has not many people, still you are earning an income. So, it was both ways." "But i knew, i had did my calculations, i saw if $i$ can make with this manual machine, if $i$ can make three bags, and i sell, per day! by the end of sell, I sell out 500 , that is 1,500 , with zero cost because it is manual, and I am the one making it. So, 1,500 times thirty days, it is more than what a new graduate can be paid. So, I saw it was better I start my own empire instead of being employed."-[G]. "So, when I came back to Kenya, we aggressively set up the production facility. We brought in the technology, finished up last year and end of 2017, we started production."-[M]. "We started commercial production of it with the patent, local and

international. It's a different one, yeah. Plastic, biomass, power production, water purification, agro, consultancy, medical, you know, all these enterprises! So, to me waste is not waste, waste is a resource. We are in fertilizer, we are in plastic, we are in charcoal briquettes, we are in energy production, and we are in jewellery and we are in water. But they ran as different entities. The only common person here is Oscar. Are you getting me? I mean, I've got numerous innovations, all these organizations, all the 16 organizations I have are all innovations (laughs). That's how an innovation comes in. Then, I need to commercialize. That's what it turns out to be."-[O]." So, at that point, when I gave Mr. Dan the product, he used the product in his farm and, surprisingly, he actually doubled his yields for that season. He was so much excited that he called me for 'Mbuzi choma', you know. (Laughs), yeah! So, it was very interesting and from there, now we thought, now we have a product for the farm and that is the way SO Agro was founded. So, now, the following year-2015, we registered SO Agro and incorporated it and started, now definitely, with growth. So, basically, I am the founder and CEO of the company."-[S]. "So, I did that for a while and as well as i still continue doing my ordinary business of selling windows, doors and gates, and fabricating them. Then I realized that there's a gap somewhere. When I was doing those Jikos, I realized there is a gap in energy sector.

I realized that there was a gap in energy sector, I started venturing into energy. I started looking for the customers and I realized there was so much biomass waste. "-[P]. 


\section{References}

1. Littlewood, D.; Holt, D. Social and Environmental Enterprises in Africa: Context, Convergence and Characteristics. In The Business of Social and Environmental Innovation; Bitz, V., Hamann, R., Hall, M., Griffin, E.L., Eds.; Springer: Berlin/Heidelberg, Germany, 2015; pp. 27-48.

2. Holt, D.; Littlewood, D. Waste Livelihoods amongst the Poor-Through the Lens of Bricolage. Bus. Strat. Environ. 2017, 26, 253-264. [CrossRef]

3. Naudé, W. Entrepreneurship, developing countries, and development economics: New approaches and insights. Small Bus. Econ. 2010, 34, 1-12. [CrossRef]

4. Baldassarre, B.; Calabretta, G.; Bocken, N.; Jaskiewicz, T. Bridging sustainable business model innovation and user-driven innovation: A process for sustainable value proposition design. J. Clean. Prod. 2017, 147, 175-186. [CrossRef]

5. Bocken, N.M.P.; Short, S.W.; Rana, P.; Evans, S. A literature and practice review to develop sustainable business model archetypes. J. Clean. Prod. 2014, 65, 42-56. [CrossRef]

6. Thompson, N.; Kiefer, K.; York, J.G. Distinctions not Dichotomies: Exploring Social, Sustainable, and Environmental Entrepreneurship. In Social and Sustainable Entrepreneurship (Advances in Entrepreneurship, Firm Emergence and Growth); Lumpkin, G., Katz, J.A., Eds.; Emerald Group Publishing Limited: Bringley, UK, 2011; Volume 13, pp. 201-229.

7. Schaltegger, S.; Wagner, M. Sustainable entrepreneurship and sustainability innovation: Categories and interactions. Bus. Strat. Environ. 2011, 20, 222-237. [CrossRef]

8. Wiklund, J.; Davidsson, P.; Audretsch, D.B.; Karlsson, C. The Future of Entrepreneurship Research. Entrep. Theory Pract. 2011, 35, 1-9. [CrossRef]

9. Azmat, F. Sustainable Development in Developing Countries: The Role of Social Entrepreneurs. Int. J. Public Adm. 2013, 36, 293-304. [CrossRef]

10. Prahalad, C.K.; Ramaswamy, V. Co-creation experiences: The next practice in value creation. J. Interact. Mark. 2004, 18, 5-14. [CrossRef]

11. World Bank. World Development Indicators; World Bank: Washington, DC, USA, 2012.

12. Sarkar, S.; Pansera, M. Sustainability-driven innovation at the bottom: Insights from grassroots ecopreneurs. Technol. Forecast. Soc. Chang. 2017, 114, 327-338. [CrossRef]

13. Cohen, B.; Winn, M.I. Market imperfections, opportunity and sustainable entrepreneurship. J. Bus. Ventur. 2007, 22, 29-49. [CrossRef]

14. Patzelt, H.; Shepherd, D.A. Recognizing opportunities for sustainable development. Entrep. Theory Pract. 2010, 35, 631-652. [CrossRef]

15. Hanohov, R.; Baldacchino, L. Opportunity recognition in sustainable entrepreneurship: An exploratory study. Int. J. Entrep. Behav. Res. 2018, 24, 333-358. [CrossRef]

16. Conger, M.; McMullen, J.S.; Bergman, B.J.; York, J.G. Category membership, identity control, and the reevaluation of prosocial opportunities. J. Bus. Ventur. 2018, 33, 179-206. [CrossRef]

17. Hall, J.K.; Daneke, G.A.; Lenox, M.J. Sustainable development and entrepreneurship: Past contributions and future directions. J. Bus. Ventur. 2010, 25, 439-448. [CrossRef]

18. Lumpkin, G.; Moss, T.W.; Gras, D.M.; Kato, S.; Amezcua, A.S. Entrepreneurial processes in social contexts: How are they different, if at all? Small Bus. Econ. 2013, 40, 761-783. [CrossRef]

19. Nicolopoulou, K. Social entrepreneurship between cross-currents: Toward a framework for theoretical restructuring of the field. J. Small Bus. Manag. 2014, 52, 678-702. [CrossRef]

20. Belz, F.M.; Binder, J.K. Sustainable Entrepreneurship: A Convergent Process Model. Bus. Strat. Environ. 2017, 26, 1-17. [CrossRef]

21. Hoang, H.; Gimeno, J. Becoming a founder: How founder role identity affects entrepreneurial transitions and persistence in founding. J. Bus. Ventur. 2010, 25, 41-53. [CrossRef]

22. Shepherd, D.A.; Williams, T.A.; Patzelt, H. Thinking about Entrepreneurial Decision Making: Review and Research Agenda. J. Manag. 2015, 41, 11-46. [CrossRef]

23. Powell, E.E.; Baker, T. In the beginning: Identity processes and organizing in multi-founder nascent ventures. Acad. Manag. J. 2017, 60, 2381-2414. [CrossRef]

24. Fauchart, E.; Gruber, M. Darwinians, communitarians, and missionaries: The role of founder identity in entrepreneurship. Acad. Manag. J. 2011, 54, 935-957. [CrossRef]

25. Sarango-Lalangui, P.; Santos, J.L.S.; Hormiga, E. The development of sustainable entrepreneurship research field. Sustainability 2018, 10, 2005. [CrossRef]

26. Hörisch, J. The Role of Sustainable Entrepreneurship in Sustainability Transitions: A Conceptual Synthesis against the Background of the Multi-Level Perspective. Adm. Sci. 2015, 5, 286-300. [CrossRef]

27. Abrams, D.E.; Hogg, M.A. Social Identity Theory: Constructive and Critical Advances; Springer: London, UK, 1990.

28. Stryker, S.; Burke, P.J. The Past, Present, and Future of an Identity Theory. Soc. Psychol. Q. 2000, 63, 284. [CrossRef]

29. Dacin, M.T.; Dacin, P.A.; Tracey, P. Social entrepreneurship: A critique and future directions. Organ. Sci. 2011, $22,1203-1213$. [CrossRef] 
30. Sarkar, S. Grassroots entrepreneurs and social change at the bottom of the pyramid: The role of bricolage. Entrep. Reg. Dev. 2018, 30, 421-449. [CrossRef]

31. Schaltegger, S.; Freund, F.L.; Hansen, E.G. Business cases for sustainability: The role of business model innovation for corporate sustainability. Int. J. Innov. Sustain. Dev. 2012, 6, 95. [CrossRef]

32. Tajfel, H.; Turner, J.C. An integrative theory of intergroup conflict. In The Social Psychology of Intergroup Relations; Austin, W.G., Worchel, S., Eds.; Brooks-Cole: Monterey, CA, USA, 1979; pp. 33-47.

33. Żur, A. Entrepreneurial Identity and Social-Business Tensions-The Experience of Social Entrepreneurs. J. Soc. Entrep. 2020, 1-24. [CrossRef]

34. Parrish, B.D. Sustainability-driven entrepreneurship: Principles of organization design. J. Bus. Ventur. 2010, 25, 510-523. [CrossRef]

35. Gruber, M.; Macmillan, I.C. Entrepreneurial Behavior: A Reconceptualization and Extension Based on Identity Theory. Strat. Entrep. J. 2017, 11, 271-286. [CrossRef]

36. Wry, T.; York, J.G. An Identity-Based Approach to Social Enterprise. Acad. Manag. Rev. 2015, 42, 437-460. Available online: http: / / eds.a.ebscohost.com/eds / pdfviewer / pdfviewer?vid=1\&sid=61733f9f-76cb-49f6-8999-5090512bc763\%40sessionmgr4010 (accessed on 18 September 2020). [CrossRef]

37. O'Neil, I.; Ucbasaran, D. Balancing "what matters to me" with "what matters to them": Exploring the legitimation process of environmental entrepreneurs. J. Bus. Ventur. 2016, 31, 133-152. [CrossRef]

38. York, J.G.; O'Neil, I.; Sarasvathy, S.D. Exploring Environmental Entrepreneurship: Identity Coupling, Venture Goals, and Stakeholder Incentives. J. Manag. Stud. 2016, 53, 695-737. [CrossRef]

39. Yitshaki, R.; Kropp, F. Entrepreneurial passions and identities in different contexts: A comparison between high-tech and social entrepreneurs. Entrep. Reg. Dev. 2016, 28, 206-233. [CrossRef]

40. Seyfang, G.; Haxeltine, A. Growing grassroots innovations: Exploring the role of community-based initiatives in governing sustainable energy transitions. Environ. Plan. C Gov. Policy 2012, 30, 381-400. [CrossRef]

41. Smith, A.; Fressoli, M.; Thomas, H. Grassroots Innovation Movements: Challenges and Contributions. J. Clean. Prod. 2014, 63, 114-124. [CrossRef]

42. Murnieks, C.; Mosakowski, E. Who Am: I? Looking Inside the "Entrepreneurial Identity". 2007. Available online: https: / / ssrn.com/abstract=1064901 (accessed on 6 October 2020).

43. Stryker, S. Self, Identity, and Social Movements; University of Minnesota Press: Minneapolis, MN, USA, 2000.

44. O'Neil, I.; Ucbasaran, D.; York, J.G. The evolution of founder identity as an authenticity work process. J. Bus. Ventur. 2020, 106031. [CrossRef]

45. Jones, J.J.; York, J.G. Fitting in and standing out: An identity approach for sustainable entrepreneurs. In Sustainable Entrepreneurship: Discovering, Creating and Seizing Opportunities for Blended Value Generation; Lindgreen, A., Maon, F., Vallaster, C., Yousafzai, S., Florencio, B.P., Eds.; Routledge: New York, NY, USA, 2019; pp. 1-33.

46. Leitch, C.M.; Harrison, R.T. Identity, identity formation and identity work in entrepreneurship: Conceptual developments and empirical applications. Entrep. Reg. Dev. 2016, 28, 177-190. [CrossRef]

47. Mmbaga, N.A.; Mathias, B.D.; Williams, D.W.; Cardon, M.S. A review of and future agenda for research on identity in entrepreneurship. J. Bus. Ventur. 2020, 35, 106049. [CrossRef]

48. Grimes, M.G. The pivot: How founders respond to feedback through idea and identity work. Acad. Manag. J. 2018, 61, 1692-1717. [CrossRef]

49. Murnieks, C.Y.; Mosakowski, E.; Cardon, M.S. Pathways of Passion: Identity Centrality, Passion, and Behavior among Entrepreneurs. J. Manag. 2014, 40, 1583-1606. [CrossRef]

50. Brändle, L.; Berger, E.S.; Golla, S.; Kuckertz, A. I am what I am-How nascent entrepreneurs' social identity affects their entrepreneurial self-efficacy. J. Bus. Ventur. Insights 2018, 9, 17-23. [CrossRef]

51. O'Neill, K.J.; Gibbs, D. Rethinking green entrepreneurship-Fluid narratives of the green economy. Environ. Plan. A Econ. Space 2016, 48, 1727-1749. [CrossRef]

52. Murnieks, C.Y. Who Am I? The Quest for an Entrepreneurial Identity and an Investigation of Its Relationship to Entrepreneurial Passion and Goal-Setting; University of Colorado: Boulder, CO, USA, 2007.

53. Cardon, M.; Wincent, J.; Singh, J.; Drnovsek, M. The nature and experience of entrepreneurial passion. Acad. Manag. Rev. 2009, 34, 511-532. [CrossRef]

54. Powell, E.E.; Baker, T. It's what you make of it: Founder identity and enacting strategic responses to adversity. Acad. Manag. J. 2014, 57, 1406-1433. [CrossRef]

55. Mathias, B.D.; Williams, D.W. Giving up the hats? Entrepreneurs' role transitions and venture growth. J. Bus. Ventur. 2018, 33, 261-277. [CrossRef]

56. Hogg, M.A.; Terry, D.J. Social Identity and Self-Categorization Processes in Organizational Contexts. Acad. Manag. Rev. 2000, 25, 121. [CrossRef]

57. Cannella, A.A.; Jones, C.D.; Withers, M.C. Family-versus lone-founder-controlled public corporations: Social identity theory and boards of directors. Acad. Manag. J. 2015, 58, 436-459. [CrossRef]

58. Prahalad, C.K. Bottom of the pyramid as a source of breakthrough innovations. J. Prod. Innov. Manag. 2011, 29, 6-12. [CrossRef] 
59. Hoogendoorn, B. The Prevalence and Determinants of Social Entrepreneurship at the Macro Level. J. Small Bus. Manag. 2016, 54, 278-296. [CrossRef]

60. Seelos, C.; Mair, J. Social entrepreneurship: Creating new business models to serve the poor. Bus. Horiz. 2005, 48, 241-246. [CrossRef]

61. Shaw, E.; Carter, S. Social entrepreneurship: Theoretical antecedents and empirical analysis of entrepreneurial processes and outcomes. J. Small Bus. Enterp. Dev. 2007, 14, 418-434. [CrossRef]

62. Hörisch, J.; Kollat, J.; Brieger, S.A. What influences environmental entrepreneurship? A multilevel analysis of the determinants of entrepreneurs' environmental orientation. Small Bus. Econ. 2016, 48, 47-69. [CrossRef]

63. Meek, W.R.; Pacheco, D.F.; York, J.G. The impact of social norms on entrepreneurial action: Evidence from the environmental entrepreneurship context. J. Bus. Ventur. 2010, 25, 493-509. [CrossRef]

64. Shepherd, D.A.; Patzelt, H. The New Field of Sustainable Entrepreneurship: Studying Entrepreneurial Action Linking "What Is to Be Sustained" with "What Is to Be Developed". Entrep. Theory Pract. 2011, 35, 137-163. [CrossRef]

65. Thompson, N.A.; Herrmann, A.M.; Hekkert, M. How sustainable entrepreneurs engage in institutional change: Insights from biomass torrefaction in the Netherlands. J. Clean. Prod. 2015, 106, 608-618. [CrossRef]

66. Parris, M.T.; Kates, W.R. Characterizing and Measuring Sustainable Development. Annu. Rev. Environ. Resour. 2003, 28, 559-586. [CrossRef]

67. York, J.G.; Hargrave, T.J.; Pacheco, D.F. Converging winds: Logic hybridization in the Colorado wind energy field. Acad. Manag. J. 2016, 59, 579-610. [CrossRef]

68. Pinkse, J.; Groot, K. Sustainable Entrepreneurship and Corporate Political Activity: Overcoming Market Barriers in the Clean Energy Sector. Entrep. Theory Pract. 2013, 39, 633-654. [CrossRef]

69. Dean, T.J.; McMullen, J.S. Toward a theory of sustainable entrepreneurship: Reducing environmental degradation through entrepreneurial action. J. Bus. Ventur. 2007, 22, 50-76. [CrossRef]

70. Pacheco, D.F.; Dean, T.J.; Payne, D.S. Escaping the green prison: Entrepreneurship and the creation of opportunities for sustainable development. J. Bus. Ventur. 2010, 25, 464-480. [CrossRef]

71. Hoogendoorn, B.; Van Der Zwan, P.; Thurik, R. Sustainable Entrepreneurship: The Role of Perceived Barriers and Risk. J. Bus. Ethics 2019, 157, 1133-1154. [CrossRef]

72. Estrin, S.; Mickiewicz, T.; Stephan, U. Entrepreneurship, Social Capital, and Institutions: Social and Commercial Entrepreneurship across Nations. Entrep. Theory Pract. 2013, 37, 479-504. [CrossRef]

73. Hockerts, K.; Wüstenhagen, R. Journal of Business Venturing Greening Goliaths versus emerging Davids-Theorizing about the role of incumbents and new entrants in sustainable entrepreneurship. J. Bus. Ventur. 2010, 25, 481-492. [CrossRef]

74. Prahalad, C.K. Fortune at the Bottom of the Pyramid: Eradicating Poverty through Profits; Wharton School Publishing: Upper Saddle River, NJ, USA, 2004.

75. Ladd, T. Business models at the bottom of the pyramid: Leveraging context in undeveloped markets. Int. J. Entrep. Innov. 2017, 18, 57-64. [CrossRef]

76. Tracey, P.; Phillips, N. Entrepreneurship in emerging markets strategies for new venture creation in uncertain institutional contexts. Manag. Int. Rev. 2011, 51, 23-39. [CrossRef]

77. Acs, Z.J.; Desai, S.; Hessels, J. Entrepreneurship, economic development and institutions. Small Bus. Econ. 2008, 31, $219-234$. [CrossRef]

78. Eijdenberg, E.L.; Paas, L.J.; Masurel, E. Entrepreneurial motivation and small business growth in Rwanda. J. Entrep. Emerg. Econ. 2015, 7, 212-240. [CrossRef]

79. Monaghan, A. Conceptual niche management of grassroots innovation for sustainability: The case of body disposal practices in the UK. Technol. Forecast. Soc. Chang. 2009, 76, 1026-1043. [CrossRef]

80. Hargreaves, T.; Hielscher, S.; Seyfang, G.; Smith, A. Grassroots innovations in community energy: The role of intermediaries in niche development. Glob. Environ. Chang. 2013, 23, 868-880. [CrossRef]

81. Agnihotri, A. Doing good and doing business at the bottom of the pyramid. Bus. Horiz. 2013, 56, 591-599. [CrossRef]

82. Hossain, M. Grassroots innovation: A systematic review of two decades of research. J. Clean. Prod. 2016, 137, 973-981. [CrossRef]

83. Pansera, M.; Owen, R.J. Framing resource-constrained innovation at the 'bottom of the pyramid': Insights from an ethnographic case study in rural Bangladesh. Technol. Forecast. Soc. Chang. 2015, 92, 300-311. [CrossRef]

84. Viswanathan, M.; Seth, A.; Gau, R.; Chaturvedi, A. Doing Well by Doing Good: Pursuing Commercial Success by Internalizing Social Good in Subsistence Markets. Acad. Manag. Proc. 2007, 1, 1-6. [CrossRef]

85. Eggers, F. Grow with the flow: Entrepreneurial marketing and thriving young firms. Int. J. Entrep. Ventur. 2010, 1, 227. [CrossRef]

86. Denzin, N.K.; Lincoln, Y.S.; Giardina, M.D. Disciplining Qualitative research. Int. J. Qual. Stud. Educ. 2006, 19, 769-782. [CrossRef]

87. Eisenhardt, K.M. Building Theories form Case Studies. Acad. Manag. Rev. 1989, 14, 532-550. [CrossRef]

88. Yin, R.K. Case Study Research Design and Methods, 2nd ed.; Sage Publications Inc.: Thousand Oaks, CA, USA, 1994.

89. Yin, R.K. Case Study Research: Design and Methods; Sage Publications: Thousand Oaks, CA, USA, 2009.

90. Flick, U. An Introduction to Qualitative Research; Sage Publications: Thousand Oaks, CA, USA, 2009.

91. Denzin, N.K.; Lincoln, Y.S. The Sage Handbook of Qualitative Research; Sage Publications Inc.: Thousand Oaks, CA, USA, 2005.

92. Miles, M.B.; Huberman, A.M. Qualitative Data Analysis: An Expanded Sourcebook, 2nd ed.; SAGE Publications Ltd.: Thousand Oaks, CA, USA, 2003. 
93. Strauss, A.; Corbin, J. Basics of Qualitative Research: Techniques and Procedures for Developing Grounded Theory, 2nd ed.; Sage Publications Inc.: Newbury Park, CA, USA, 1998.

94. Risi, D.; Wickert, C. Reconsidering the "symmetry" between institutionalization and professionalization: The case of corporate social responsibility managers. J. Manag. Stud. 2017, 54, 613-646. [CrossRef]

95. Ceptureanu, E.G.; Ceptureanu, S.I.; Orzan, M.C.; Bordean, O.; Violeta, R. Empirical study on sustainable opportunities recognition. a polyvinyl chloride (PVC) joinery industry analysis using augmented sustainable development process model. Sustainability 2017, 9, 1779. [CrossRef]

96. Alsos, G.A.; Clausen, T.H.; Hytti, U.; Solvoll, S. Entrepreneurs' social identity and the preference of causal and effectual behaviours in start-up processes. Entrep. Reg. Dev. 2016, 28, 234-258. [CrossRef]

97. Shepherd, D.; Haynie, J.M. Birds of a feather don't always flock together: Identity management in entrepreneurship. J. Bus. Ventur. 2009, 24, 316-337. [CrossRef]

98. Hoang, H.; Antoncic, B. Network-based research in entrepreneurship: A critical review. J. Bus. Ventur. 2003, 18, 165-187. [CrossRef] 